\title{
A fotomontagem como função política
}

Annateresa FABRIS ${ }^{2}$

RESUMO: O movimento dadá em Berlim distingue-se por um projeto de intervenção política, em sintonia com a orientação ideológica de vários de seus integrantes. Entre estes pode ser destacado John H eartfield, interessado, desde 1915, em desenvolver uma linguagem ao mesmo tempo moderna e acessível a um público de massa. Para tanto, lança mão da fotografia nas capas executadas para a editora $M$ al ik e é responsável pelo desenvolvimento da fotomontagem política, que divulga sobretudo numa revista do Partido Comunista Alemão, o Arbeiter Illustrierte Zeitung.

PalaV ras-chaVe: Dadaísmo, fotomontagem, Nazismo.

Cubismo e Futurismo haviam introduzido no interior da maté ria pictórica eescultórica materiais heterogêneos, provenientes do universo industrial e da sociedade de massa, dando vida à colagem eà escultura polimatérica. 0 princípio polimatérico, graças ao qual são negados os materiais tradicionais da arte, a fim de nela introduzir a realidade - quer enquanto ponte entre a dimensão estética e o mundo tecnológico, quer como abertura de novos caminhos expressivos - , pode ser colocado na base da idéia da colagem e do assemblage. Boccioni, que desde 1911, concebia a criação como um elemento abarcador para além de toda especialização e hierarquia, propõe no ano seguinte introduzir na arte a dimensão real, ${ }^{3}$ como demonstram 0 manifesto "A escultura futurista" (publicado no mês de abril), e obras como Fusão de cabeça e janela, constituída pela integração de uma escultura dotada de cabelos num chassi de janela, eC abeça + Casa + Luz, na qual um busto de gesso convive com al guns detal hes verdadeiros como uma balaustrada de ferro.

Em maio de 1912, Picasso realiza sua primeira colagem, Natureza-morta com cadeira de palhinha, ao introduzir num pequeno quadro 
oval um pedaço de oleado cujo desenho imitava um fundo de cadeira; em setembro do mesmo ano, Braque utiliza a técnica do papier collé numa outra natureza-morta, Frutei ra e copo. Se Renato Barilli detecta na primeira colagem picassiana uma mediação entre a simulação bidimensional e a concretude tridimensional da coisa em si, e considera o papier collé uma variante mais tímida da experimentação de Picasso, mais próxima da virtualidade e da ilusão, ${ }^{4}$ bem diferente é o juízo de John Golding. Usando genericamente o termo colagem, Golding atribui à nova técnica o "golpe mais violento" desfechado contra a pintura tradicional e, sobretudo, contra "a concepção idealista e sentimental da 'obra de arte', concebida como a expressão não somente de um certo saber técnico, mas também de um tipo de beleza absoluta". 5

D ouglas Cooper, por sua vez, propõe uma distinção entre colagem e papier collé: a primeira designa a introdução de um elemento real numa representação ( pintada) da realidade; o segundo, em cuja base está a idéia de Braque de que a cor poderia ser tratada como um elemento independente da composição, não só pode vir a constituir a base cromática de uma obra, como pode receber intervenções gráficas, funcionando tanto como fundo quanto como representação ilusionista no primeiro plano. 0 choque instaurado por Natureza-morta com cadeira de palhinha, graças à qual Picasso havia colocado em xeque as concepções ilusionistas de pintura, teria sido aprofundado pela técnica do papier collé, que propunha uma relação ainda mais paradoxal entre verdadeiro e falso. O s diversos tipos de papel colados numa superfícieeram literalmente reais - por serem fragmentos do mundo exterior - , mas não deixavam de ser falsos tanto quanto os objetos pintados, na medida em que pretendiam passar por um outro material, quando não por uma figura. ${ }^{6}$

Qualquer que seja a avaliação plástica suscitada por essas primeiras experiências, éinegável que a introdução de objetos e de refugos de materiais retirados do contexto cotidiano gera umatensão entreo mundo real e o mundo imitado (o quadro), da qual deriva um questionamento dos fundamentos tradicionais da pintura. A colagem, de fato, coloca em xeque a idéia convencional de representação, ao confrontar o artista com a possibilidade de renunciar à imitação graças a uma es- 
tratégia de caráter dialético: a obra está ao mesmo tempo sob o signo da referência a uma realidade exterior e da negação dessa possi bilidade em virtude da integração do fragmento real numa estrutura compositiva. ${ }^{7}$

É levando em conta essa dupla articulação da colagem que François Laplantine e Alexis N ouss situam a técnica sob o signo da mestiçagem formal. Ao criar ao mesmo tempo um reflexo da realidade exterior ( pelo uso de materiais já existentes) e uma nova realidade (pelo choque da aproximação), a colagem pode ser considerada como portadora de um novo tipo de beleza, que deitaria raízes numa fulguração a partir do real. A ruptura da unidade da superfície pictórica dela decorrente não deve ser vista apenas como um questionamento da idéia clássica de profundidade. É também uma demonstração do modus operandi dos pintores cubistas, que quebram as formas e justapõem os fragmentos com o objetivo de produzir uma nova composição que guarda em seu interior as marcas da ruptura. ${ }^{8}$

Por isso, parece insuficiente hoje em dia a hipótese formulada em 1912 por M aurice Raynal, que atribuía o aparecimento da colagem ao descontentamento dos artistas em relação ao ilusionismo fotográfico na pintura, do qual derivaria a decisão de substituir a cópia fiel de um objeto pela introdução de partes desse mesmo objeto na obra de arte. ${ }^{9}$ Bem mais produtiva é a leitura proposta por Edmond Couchot, que estabelece um elo entre a colagem e uma parcela do universo da moderna comunicação de massa: os olhos de Picasso e de Braque estariam acostumados à fusão íntima de texto e imagem (sobretudo fotográfica) graças à propagação da imprensa e das revistas ilustradas. Couchot leva ainda mais longe seu raciocínio e localiza em algumas características da imprensa do começo do século XX a presença de estratégias visuais que seriam divulgadas pelo Cubismo em termos artísticos. Em primeiro lugar, atribui a estrutura da nova visualidade à visão das páginas dos jornais ilustrados, que podem ser considerados "uma espécie de quadro cubista no qual coabitam espaços heterogêneos (...), sem ponto de vista único, ao mesmo tempo estilhaçados e ordenados". Em segundo lugar, propõe um paral el o com a composição tipográfica como manipulação de objetos e de materiais, e os procedimentos cubis- 
tas de amalgamar elementos de diferentes procedências, entre os quais destaca a colagem, que transforma o objeto em imagem no momento em que o projeta realmente na tela. ${ }^{10}$

Francis Frascina propõe um outro tipo de aproximação entre a colagem e a imprensa, ao detectar no uso de recortes de jornal por parte de Picasso uma atitude contrária àquela ostentada por simbolistas e neo-simbolistas, que desprezavam o rebaixamento literário propiciado pelo jornalismo e elevavam o livro a instrumento espiritual. A escolha de um formato particular de material de imprensa - tiras de jornal - para integrar as colagens é vista como uma outra negação dos valores simbolistas. 0 autor lembra que os efeitos ópticos e auditivos que caracterizavam a poesi a de $\mathrm{M}$ allarmé se apresentavam como uma antítese das colunas verticais do jornal e, portanto, do mercado de massa. Ao utilizar materiais que eram desprezados pelos defensores da arte pura - recortes de jornal sobre acontecimentos sociopolíticos contemporâneos, ficção romântica serializada, anúncios - , Picasso acaba por tornar instáveis os limites convencionais entre "arte" e "cultura de massa". ${ }^{11}$

$\mathrm{N}$ ão se pode esquecer, por outro lado, que a fotografia havia fomentado no século XIX o desenvolvimento de um gênero bastante fantasioso no âmbito da cultura popular, divulgado por revistas e cartões postais, sobretudo. Não é improvável que Picasso tenha tido contato com colagens fotográficas populares, caracterizadas quase sempre por combinações bizarras de objetos disparatados e por uma visualidade que, não raro, antecipa o Surrealismo, uma vez que é conhecido seu interesse pela fotografia. Anne Baldassari destaca em sua coleção a presença de cartões postais de costumes regionais, freqüentemente coloridos à mão e bordados, que o encantavam por sua ingenuidade e desinibição. ${ }^{12}$

O princípio da colagem, aliado ao exemplo das palavras em liberdade futuristas, encontrará um campo fértil de pesquisa no grupo dadaísta de Berlim, transformando-se em fotomontagem. 0 objet trouvé duchampiano transforma-se em image trouvée, de acordo com dois dos eixos fundamentais da plataforma dadaísta: a destruição das velhas lin- 
guagens e a proposta de novas possi bilidades lingüísticas graças à adesão dos artistas às solicitações da sociedade urbana.

Da mesma forma que a colagem, também a fotomontagem tem raízes populares, apontadas por Hannah Höch e Raoul Hausmann. $\mathrm{H}$ annah $\mathrm{H}$ öch, em depoimento a $\mathrm{H}$ ans Richter, situa seu surgimento em 1917 ou 1918. Naquele período, ela e Hausmann haviam alugado um quarto num vilarejo do mar Báltico na temporada de verão. A artista lembra que no quarto se encontrava uma oleografia emoldurada, em cujo centro era representado o imperador Guilherme II entre seus ancestrais e descen dentes, carval hos e condecorações. Um pouco acima se via um jovem artilheiro, sob cujo capacete estava colado o retrato do proprietário da casa, de maneira a criar um elo entre ele e seus superiores. 0 caráter "paradoxal" da imagem despertou a atenção de H ausmann que, de volta a Berlim, "começou a criar produtos abstrusos através da justaposição de banalidades fotografadas", que denominou "fotomontagens". ${ }^{13}$

H ausmann, por sua vez, situa o episódio relatado pela sua então companheira em 1918 e lhe antepõe a feitura de quadros com pedaços de papel colorido e recortes de jornais e cartazes. A idéia da fotomontagem nasceu efetivamente em Heidebrink: a visão da litografia evocada por Hannah Höch provocou nele uma espécie de "iluminação", levando-o a pensar na possibilidade de compor quadros a partir de fotografias recortadas. De volta a Berlim, em setembro, começou a pôr em prática a idéia, lançando mão de imagens provenientes de revistas e filmes. Com a colaboração de Johannes Baader, George Grosz, John $\mathrm{H}$ eartfield e $\mathrm{H}$ annah $\mathrm{H}$ öch, resolveu chamar a técnica de fotomontagem, pois o grupo de Berlim preferia a imagem do engenheiro àquela do artista, afirmando construir, "montar" os próprios trabalhos. ${ }^{14}$

Ao atribuir a si mesmo, a Baader ea Hannah $\mathrm{Höch}$ o desenvolvimento da fotomontagem, H ausmann afirma que Grosz e H eartfield realizaram colagens até 1920, mas é contestado por eles. N uma carta a Franz Roh, Grosz atesta que realizou experiências de fotomontagem a partir de colagens realizadas por ele e H eartfield em 1915. Herta Wescher considera a data discutível, uma vez que o artista estava, naquele momento, na frente de batalha, tendo regressado a Berlim em 1916. Por esse moti- 
vo aponta como data mais provável para o início das experiências maio de 1916, como consta do depoimento de Grosz a Erwin Piscator, publicado em Teatro político. ${ }^{15}$

Se é difícil estabelecer com precisão o momento em que a fotomontagem é concebida, não se pode deixar de assinalar que o argumento temporal apresentado pela autora não é correto. Grosz é reformado por motivos de saúde em maio de 1915, vindo a ser reconvocado em janeiro de $1917 .{ }^{16} \mathrm{H}$ eartfield, por sua vez, afirma em suas memórias que, no fim de 1916 - quando se encontrava na frente ocidental - , recebera de Grosz uma encomenda. No papelão que a embrulhava se encontravam anúncios publicitários, rótulos de garrafas e fotografias de revistas, recortados arbitrariamente e montados de maneira absurda. Essa estrutura gerou cartões postais feitos à mão que os dois amigos trocavam entresi, nos quais as imagens justapostas diziam aquilo que as palavras não podiam afirmar por razões de censura. ${ }^{17}$

Uma vez que nenhum desses cartões chegou até nós, Dawn Ades aventa a hipótese de que eles se pareceriam com a colagem realizada por H eartfield para a propaganda do álbum litográfico Pequeno portfólio de Grosz (Neue Jugend, junho de 1917), composta a partir de imagens heterogêneas, das quais nenhuma de origem fotográfica. A composição destaca-se pelo uso de diferentes pontos de vista, que remetem tanto à espacialidade do Cubismo quanto à simultaneidade das trocas própria da atividade comercial, de acordo com a hipótese de Douglas Kahn. ${ }^{18} \mathrm{Na}$ falta de evidências concretas em relação à parceria H eartfield/Grosz, é provável que uma das primeiras fotomontagens seja Cinema sintético da pintura, realizada por Hausmann em 1918. Trata-se de um auto-retrato do artista, do qual foi isolada a boca, escancarada em primeiro plano, encimada por um ol ho entreaberto e ladeada por um outro olho dotado de um monóculo. A imagem brota do interior de uma forma circular que pode ser remetida ao dispositivo tecnológico que a gerou, impressão reforçada pelo título da composição quea ladeia em diversos caracteres tipográficos.

$\mathrm{O}$ que interessa a $\mathrm{H}$ ausmann, Baader e $\mathrm{H}$ annah $\mathrm{H}$ öch nesse momento é, sobretudo, o rompimento da uniformidade da superfície da representação graças à multiplicação dos pontos de vista e à interpe- 
netração dos diferentes fragmentos de imagens, cuja objetividade deveria ser interpretada num duplo sentido: como tomada de posi ção contra o "expressionismo pós-futurista", caracterizado pela falta de engajamento e pelo vazio conceitual, e como visualização irônica dos acontecimentos políticos contemporâneos. ${ }^{19}$ Esses aspectos destacamse de imediato em algumas produções de $\mathrm{H}$ annah $\mathrm{H}$ öch datadas de 1919. A artista, que havia feito experiências com a colagem em 1916, três anos depois realiza a fotomontagem Chefes de Estado, na qual apresenta o presidente da República de Weimar, Friedrich Ebert, e o ministro do Exército, Gustav Noske, em trajes de banho contra um fundo estampado, obtido a partir de várias sobreposições de padrões de tecidos feitas com um ferro de engomar. ${ }^{20}$

SeChefes de Estado - cujo ponto de partida é uma fotografia publicada na revista Berliner Illustrierte Zeitung - obedece a uma composição frontal, destacando-se, sobretudo, pela sátira inerente à justaposição das figuras masculinas numa situação pouco habitual com as delicadas estampas do fundo, bem diferente é a gi gantesca Corte com faca de bolo - Dadá através da cultura alemã de barriga de cerveja na última época de Weimar (1919), ritmada por uma multiplicidade de pontos de vista, que não confere destaque a nenhum motivo ou imagem isolada. A fotomontagem, feita a partir de reproduções de revistas ilustradas, prospectos técnicos, fotografias e letras sobre um papel japonês ligeiramente pintado derosa eamarelo, édefinida por Peter Krieger como: "um cortetransversal através da sociedade do tempo da guerra e do pós-guerra". Na parte superior à direita concentram-se os "antidadaístas", isto é, o imperador Guilherme II, cujo bigode éformado por dois lutadores, os generais e o príncipe herdeiro. À esquerda destaca-se a cabeça de Einstein que está observando a engrenagem do tempo. Entre os grupos de figuras, Krieger dá realcea

alguns intermezzi de um atrevimento divertido: no centro a bailarina $\mathrm{N} \mathrm{id}$ di Impekoven equilibra, de forma coquete, a cabeça de Käthe Kollwitz. Vêem-se Else Lasker-Schüler e M ax Reinhardt, sob os quais se reúnem os dadaístas no canto direito. As cabeças do superdada Baader entre Lenine e Radek formam uma trindade burlesca. Depósitos de balas, rodas den- 
tadas, automóveis, locomotivas e aviões atravessam este caleidoscópio monumental, onde as escalas e a lógica espácio-temporal foi (sic) suprimida (sic) em favor de uma presença ruidosa e turbulenta da consciência dos conteú dos típicos da época. Farsa, protesto, arrogância demoníaca face a uma sociedade abanada pelas catástrofes. Se o U lisses de James J oyce, surgido na mesma época espelhava, segundo as palavras de Hermann Broch "o dia-a-dia do mundo na época", assim refletia certamente esta poesia-visual-simultânea o clima de Berlim do pós-guerra. ${ }^{21}$

Também em 1919 Heartfield realiza uma dupla fotomontagem para a capa da revista Jedermann sein eigner Fussball (15 de fevereiro). A parte superior é constituída por uma fotografia de W ieland Herzfelde trajado à última moda, com o tronco encerrado numa bola de futebol, acenando com o chapéu e pronunciando a frase irônica que dá título à publicação ( "Cada um sua própria bola de futebol"). Na parte inferior da página abre-se um lequecom fotografias de Ebert e de membros da Assembléia Nacional de Weimar cercando o general Erich Ludendorff, que fora adjunto do marechal Paul von Hindenburg no Estado Maior a partir de 1916. 0 caráter irônico da imagem não está apenas no formato escolhido, que remete a cartões postais do final do século XIX, mas também na escrita que a acompanha: "Concurso aberto! Quem é o mais belo?? Beleza M asculina Alemã n. 1."

O clima cultural, no qual esse tipo de imagem é realizado, é vivamente evocado por Erwin Piscator, que assim se refere ao grupo dadaísta de Berlim:

O dadaísmo tornara-se perverso. A velha posição anarquista contra a burguesia bitolada, a revolta contra a arte e as demais atividades intelectuais, passara a ser mais grave, quase já se revestindo da forma de luta política. A revista Jedermann sein eigner Fussball ainda fora um insolente "épater le bourgeois". A Bancarrota (publicada por Grosz e H eartfield) já constituía um desafio à sociedade burguesa. D esenhos e versos não se orientavam mais para postulados artísticos, e sim para a eficácia política. $O$ conteúdo determinava a forma. O u melhor, formas sem objetivo, 
através de um conteúdo que rumava diretamente para um determinado alvo, recebiam de novo contornos mais rígidos e duros. ${ }^{22}$

A Bancarrota, a que Piscator faz referência, representa um empreendimento conjunto de Herzfelde, Heartfield e Grosz, que se segue à apreensão do número único de Jedermann sein eigner Fussball. A revista, cujo nome original era Die Pleite, circula entre fevereiro de 1919 e janeiro de 1920 e seu campo de atuação é a sátira política. Lançando mão dos recursos tipográficos desenvolvidos pelos dadaístas, a revista publica artigos, sátiras e anúncios, além de hospedar em cada número desenhos de Grosz. Os alvos preferidos do artista são os mesmos que haviam sido utilizados por Hannah Höch em Chefes de Estado: Ebert e Noske como representantes da al ta finança e do militarismo. ${ }^{23}$

O fato de Heartfield e Grosz trabalharem em estreita colaboração com órgãos de oposição ao governo deve ser analisado num quadro de politização da cultura, que é a marca distintiva do grupo dadaísta de Berlim. Antiprussiano, antiburguês e antiliberal, o grupo de Berlim opõe-se à República de Weimar e demonstra simpatia pela linha revolucionária da Liga Spartacus, na qual militavam Rosa Luxemburg e Karl Liebknecht. A Primeira Guerra M undial é o grande aglutinador das atitudes anticonvencionais de Herzfelde, Heartfield e Grosz, que desenvolvem ações desestabilizadoras da ordem a fim de protestar contra o militarismo e o patriotismo alemães. H eartfield, cujo nome verdadeiro era Helmut Herzfeld, assume sua nova identidade em 1916 para testemunhar a própria solidariedade à Inglaterra, alvo de uma campanha de ódio por parte do governo alemão. 0 amigo Georg Gross transforma-se em George Grosz, atraído pelo mito da América e para expressar o próprio repúdio pela mentalidade alemã. 0 irmão Wieland acrescenta um e ao nome de família e notabiliza-se pela realização de uma das primei ras ações artísticas de caráter político. Depois do fim da guerra, andava pelas ruas de Berlim com uma única face barbeada e usando um uniforme militar ensebado a fim de desacreditar o exército e sublinhar os horrores da guerra.

Essas ações si mbólicas e a publicação de revistas como N eue Jugend (empreendimento dos "irmãos Heartfield/H erzfelde") e Die freie 
Strasse (Hausmann) podem ser enquadradas no momento pré-dadaísta. $O$ grupo, que vai se constituindo entre 1916 e 1917 com as adesões de Heartfield, Grosz, H annah Höch, Otto Dix, Hausmann, Baader, Richard Huelsenbeck, H erzfelde, Walter M ehring e Franz Jung, deixa de lado os gestos provocatórios no final de 1918, sob o impacto da revolução de novembro, que havia posto fim ao reinado dos Hohenzollern e levado ao poder a social-democracia. A Alemanha vivia um momento particularmente crítico, marcado por uma inflação desenfreada e por fortes tensões sociais, o que leva a projetar na República de Weimar a esperança de uma regeneração da sociedade.

Vendo na arte uma "arma de classe", o grupo dadaísta de Berlim não só coloca em xeque alguns dos pressupostos fundamentais do Socialismo, como se posiciona decididamente contra o Expressionismo. No plano político, realiza uma série de manifestações político-parodistas contrárias à República de Weimar, por intermédio de Baader, Hausmann e Huelsenbeck, e defende a construção de uma sociedade mais justa, ${ }^{24}$ alinhando-se às posições espartaquistas.

No plano artístico, propõe uma contraposição radical entre a vivência do momento atual, que considera uma prerrogativa própria, e a reação contra o tempo, que atribui ao Expressionismo. Um texto de Huelsenbeck, publicado no Almanaque Dadá de 1920, não deixa dúvidas a esse respeito. 0 Expressionismo éapresentado como "o gesto dos homens cansados, que desejam sair de si mesmos para esquecer a guerra ea miséria. (...) Os expressionistas são homens cansados, que se afastam da natureza, que não ousam olhar de frente a cruel dade do tempo". Dadá, ao contrário, "é a valentia em si, Dadá expõe-se ao risco da própria morte. Dadá instala-se em cheio nas coisas". Se o Expressionismo "queria se perder, Dadá quer afirmar-se". Se o Expressionismo "era harmonioso, místico, angélico", Dadá “é o rangido dos pneus e os gritos dos pregões na Bolsa de M ercadorias de Chicago". 25

A convergência entre a atitude antiartística dos dadaístas e a radicalização política que estava tomando conta de Berlim pode ser resumida nas palavras de Piscator:

Os iconoclastas faziam tábula rasa de tudo, invertiam os sinais e, vindos do campo burguês, se acercavam do mesmo princípio a partir do qual 
também o proletariado iria chegar à arte. Enquanto os elementos do sentimento adquiridos em 1918/19 se firmavam cada vez mais e as concretas exigências políticas se revestiam de contornos cada vez mais nítidos, os dadaístas, por seu lado, despiam a arte de seu sentimento ou - segundo a mais recente terminologia - a "congelavam", "a esfriavam". ${ }^{26}$

A fotomontagem inscreve-se, sem dúvida, na inversão de sinais detectada por Piscator no ambiente cultural de Berlim no período imediatamente posterior ao fim da Primeira Guerra M undial. Se o Expressionismo era o grande alvo dos dadaístas, não se pode esquecer que sua polêmica contra o mundo da arte era mais vasta, englobando a transformação radical de todos os gêneros e de todas as técnicas. N ão se tratava de postular novas leis estéticas, e sim de buscar novos conteúdos que pudessem ser traduzidos por novos materiais. É a essa busca que a fotomontagem oferece uma resposta não só pela ironia política que permeava suas melhores produções, mas também pela escolha da fotografia, "meio de expressão universalmente compreensível do mesmo modo que a linguagem", de acordo com Siegfried Kracauer. ${ }^{27}$

A observação do autor alemão permite a aproximação com uma das principais fontes da fotomontagem: as revistas ilustradas, que conhecem um notável incremento na República de Weimar. Nesse período são fundadas várias revistas ilustradas nas principais cidades alemãseseassisteà renovação de periódicosjátradicionais, como a Berliner Illustrierte Zeitung, cuja origem remonta a 1892. Não é por acaso que Hannah Höch recorre a uma fotografia publicada nela para realizar Chefes de Estado; porquanto a Berliner Illustrierte Zeitung era a maior revista ilustrada da Eu ropa, tendo atingido nos anos 20 uma tiragem de dois milhões de exemplares. Para o sucesso da revista e de outras publicações semelhantes são decisivos dois fatores: a colaboração dos mais importantes repórteres fotográficos da época (Erich Salomon, Alfred Eisenstaedt, Tim Gidal, André Kértesz, Germaine Krull, Umbo, Felix Man, Fritz Goro, Willi Ruge e M artin M unkacsi) e o surgimento do trabal ho criativo de edição. ${ }^{28}$

N esse aspecto destaca-se a contribuição de Stefan Lorant, que deixa de lado a fotografia isolada em prol da reportagem, isto é, de uma 
história contada por uma sucessão de imagens. A reportagem fotográfica, dotada de um começo e de um fim que eram definidos pelas unidades de tempo, lugar e ação, articulava-se em volta de uma imagem central, capaz de resumir todos os el ementos da história, e de um determinado número de fotografias que a ladeavam de maneira a detaIhar o enredo principal. ${ }^{29}$

É justamente contra essa inovação que Kracauer se posiciona criticamente em 1927. Vendo nas revistas ilustradas um instrumento de coerção ideológica a serviço da classe dominante, o autor detecta um ulterior perigo para o conhecimento na "variegada colagem das imagens" que estava se impondo cada vez mais. "Sua contigüidade" - escreve - "exclui sistematicamente qualquer conexão que poderia abrirse para a consciência. 'A idéia ilustrada' enxota a idéia, o turbilhão de fotografias denuncia a indiferença em relação àquilo que as coisas deviam significar". ${ }^{30}$

O núcleo central da diatribe de Kracauer - a identificação da realidade com a fotografia - enforma também o pensamento de Bertolt Brecht, que detecta no fotojornalismo burguês "uma tremenda arma contra a verdade". O material apresentado diariamente pela imprensa, "que parece ter o aspecto de verdade", só serve para obscurecer os fatos, posto que a câmara é capaz de mentir tanto quanto a máquina de escrever. ${ }^{31}$

É no interior desse debate que deve ser analisado o interesse do grupo de Berlim pela fotomontagem. Confrontados com uma expansão do campo visual sem precedentes, os dadaístas lançam mão da nova técnica para colocar em crise o sistema tradicional de representação, ao qual contrapõem uma superfície dotada de múltiplos centros, de sobreposições, de nexos nem sempre lógicos, contradizendo a lógica da fotografia e propondo uma percepção crítica do significado das imagens. Instrumento de desvio de uma determinada idéia de realidade, a fotomontagem desempenha várias funções no âmbito do grupo. É crítica em termos artísticos - por desmistificar o ato criador - e sociais - por propor uma contravisão da contemporaneidade eivada de elementos irônicos e de deslocamentos de sentido. É dialética por articular um jogo contínuo entre a realidade e sua representação. É do- 
tada de um intuito didático, pois visa a educar o olhar e permitir um maior conhecimento das estruturas ópticas, psicológicas e sociais, como afirma Hausmann em 1931. ${ }^{32}$

Embora colocada sob suspeita nas primeiras fotomontagens dadaístas, a fotografia tinha outras possibilidades de uso para além da instrumentalização burguesa. É levando em conta seu aspecto de linguagem internacional acessível a todos que Heartfield se interessa por ela. Contrapõe-na ao lápis, "meio demasiado lento" para contrastar a velocidade com a qual a imprensa burguesa espalhava notícias fal sas sobre a guerra. Eficaz "instrumento de agitação das massas", a fotografia tinha uma qualidade inestimável: "apresenta o fato nu e cru eo torna facilmente compreensível; é verdade manifesta, eis sua força". 33

Se é difícil hoje em dia aceitar essa idéia ingênua de fotografia, que confunde referente e representação, não se pode esquecer que, naquele momento, a imagem técnica desempenhava uma função homológica e que a ela era confiada, entre outras, a tarefa de proporcionar uma visão crítica da sociedade. Lênin, por exemplo, recomendava o uso de fotografias dotadas de legendas no trabalho de agitação e propaganda. Nos anos 20, Franz Höllering, ao criticar a transformação da fotomontagem num passatempo burguês, incitava o operariado a usar a câmara como uma arma:

Aprenda a ver os grandes fatos simples, fotografe-os de maneira singela e clara, para que não necessitem de justificativas. Essa é sua tarefa. (...) O fotógrafo proletário deve criar documentos de sua época, não banalidades inúteis. (...) Imagens simples, claras, belas de seu mundo - esseé seu objetivo. Nada de artisticidade diletantesca. Você quer apresentar 0 mundo como ele é de verdade. ${ }^{34}$

Essa compreensão das possibilidades críticas da fotografia leva H eartfield a usá-la em larga escala no trabalho gráfico que realiza para a editora M alik, fundada em março de 1917 graças a um artifício. Heartfield e H erzfelde, entusiasmados com os desenhos duros de Grosz, resolvem divulgá-los por intermédio de uma revista. Como a abertura de novas publicações não era permitida em virtude da guerra, fazem 
um acordo com o editor de N eue Jugend e, em 1916, publicam o número 7 da revista, no qual se dissociam das edições anteriores. No ano seguinte, um desentendimento com o editor ea proibição de funcionamento de N eue Jugend ( como revista e como editora) levam H eartfield a solicitar a permissão para continuar a publicar Der M alik, romance de Else Lasker-Schüler. O recurso encontrado é ardiloso: Heartfield al ega que o romance tratava de um príncipe turco, logo, de um aliado; solicita a concessão editorial para dar continuidade à divulgação que fora iniciada em Neue Jugend, e propõe uma nova denominação para a editora. A pós a concessão da licença, H eartfield lança o romance num número duplo de N eue Jugend, editado pela M alik, utilizando uma tipografia arrojada e agressiva. Um outro número da re vista é publicado em junho do mesmo ano sob um novo disfarce: um prospecto para o Pequeno portfólio de Grosz.

Se o trabal ho publicitário realizado por Heartfield para a divulgação do conjunto de gravuras lança mão da simultaneidade cubista e das sobreposições dinâmicas que caracterizavam o estilo de Grosz, logo em seguida ele se volta para o uso da fotografia nas capas que projeta para a editora. Embora H öllering e Tretyakov coloquem toda essa produção sob o signo da fotomontagem, nem sempre Heartfield lança mão da fotografia composta. Quando o faz, como em A conquista das máquinas, de Franz Jung (1923) , apresenta uma composição bastante simples: uma mão empunhando um revólver contra um fundo formado por engrenagens em parte atravessadas por um triângulo vermelho.

A terminologia adotada por Höllering e Tretyakov foi provavelmente influenciada por uma declaração do próprio artista, que considerava fotomontagem a contigüidade estabelecida entre fotografia e recursos gráficos nas capas desenhadas ao longo da década de 20. Esse uso alargado do termo é patente na análise que Tretyakov faz da capa de Domingo sangrento, de M axim Gorki (1926):

Sob um céu cinza cossacos caval gam na estrada nevada, constelada de cadáveres humanos. Da perna voltada para baixo do número "9" escorre sangue formando uma mancha vermelha na neve. Sobre a foto, que se refere a 9 de janeiro de 1905, 0 “9" sangrento éa metáfora, a tradução do 
conceito "domingo sangrento" na linguagem da imagem e da cor, sem que a mancha escarlate altere o branco da neve, o preto das figuras, 0 cinza do céu. ${ }^{35}$

O trabalho gráfico executado para a editora Malik acaba funcionando como um elemento regulador. H eartfield deixa de lado os aspectos mais evidentemente contestadores de suas produções dadaístas, vale-se de sua formação em desenho e artes aplicadas e da experiência como desenhista publicitário de um impressor e concebe capas nas quais a mensagem do livro pudesse ser facilmente captada. Como os livros da M alik não eram muito grandes, é obrigado, em geral, a centralizar e simplificar as imagens fotográficas para que pudessem chamar a atenção rapidamente. ${ }^{36}$

$\mathrm{N}$ em por isso os resultados alcançados deixam de ser originais. Nas mãos de H eartfield as capas tornam-se parte integrante dos livros, tanto que, em vários momentos, ele substitui o título original por outro mais congenial à leitura que fazia do texto ou à imagem que havia visualizado. 0 acerto de suas escolhas é demonstrado pelo fato de outras editoras se interessarem por seu trabalho gráfico: Verlag für Literatur und Politik, Neuer D eutscher Verlag eÉdition du Carrefour (Paris), entre outras.

Além da fotomontagem, H eartfield utiliza outras combinações de recursos em sua capas. Da conjunção de fotografia e cor resultam o já citado D omingo sangrento; O utubro, de Larissa Reissner, no qual se destaca o vermelho da bandeira contra o tom cinza das pedras; A semana vermelha (1921), de Franz Jung, 0 pântano (1922) e Rei carvão (1925), de U pton Sinclair, nos quais H eartfield explora o contraste entre o preto e branco da fotografia e o vermelho das intervenções gráficas. Ainda nessa categoria realiza três versões para 100\% , de Sinclair. As duas primeiras - 1921 e 1923 - são ritmadas por uma cena urbana sobre a qual o artista imprime o título antes centralizado e depois enviesado. Na de 1928 opta por um recurso mais simples e sóbrio: a capa é dominada pela imagem de dois homens caminhando contra um fundo no qual se destaca a bandeira dos Estados Unidos, enquanto às laterais é confiado o papel de anunciar o nome do autor e do título. 
Da combinação de fotografia e texto resulta a capa de 0 preço do pecado, de Sinclair, na qual uma mão tapa a boca do protagonista um jornalista - enquanto outra Ihe oferece dinheiro. A parte textual é representada pelos nomes de grandes jornais que completam a cena.

A capa de A corrente de ouro, de Sinclair, representa uma outra possi bilidade de combinação: a de fotografia e desenho. Tretyakov assim descreve a imagem:

A capa de A corrente de ouro (...) apresenta a arte capitalista como escrava e prostituta da burguesia. Sob quadros famosos de Rembrandt, $\mathrm{H}$ als, Degas, a estátua da rainha N efertite, está sentado o proprietário burguês (...). Para reforçar o contraste entre o belo quadro e seu proprietário, no lugar de uma foto Heartfield usou um desenho de Grosz que, além de tornar monstruosa a figura do gordo capitalista, confere a toda a montagem um ar paradoxal. Os quadros fotografados são fragmentos de realidade, mas seu proprietário éirreal, uma caricatura, um fenômeno efêmero que desaparecerá. ${ }^{37}$

O trabal ho gráfico para a editora M alik, que provoca diversos episódios de censura revertidos em publicidade para o empreendimento, constitui uma das fontes do momento mais maduro de Heartfield, 0 das fotomontagens políticas. Um outro tipo de experiência éigualmente determinante nesse sentido: a colaboração com o diretor Erwin Piscator, para cujo teatro político H eartfield realiza vários cenários nos quais lança mão simultaneamente de diferentes fontes: fotografia, filme, imprensa, desenho, pintura, entre outros.

Era objetivo do teatro político fazer um trabalho de "propaganda consciente", uma vez que Piscator conferia à ação dramática a tarefa de agir sobre a razão do espectador para fomentar uma visão crítica da sociedade. Vendo nas peças "apelos" que permitiriam "intervir no fato atual e 'fazer política'", Piscator acreditava que cabia ao teatro comunicar não apenas "elevação, entusiasmo, arrebatamento, mas também esclarecimento, saber, reconhecimento". Para tanto, decide introduzir nele "a brilhante atualidade do dia de hoje, a jorrar, dominadora, de cada linha dos jornais", que deveria permitir superar o rigor que lhe parecia 
ser a marca dominante de uma concepção de arte ainda "excessivamente rígida, predeterminada elimitada no efeito". ${ }^{38}$

D ois são os principais recursos visuais mobilizados por Piscator: a projeção fotográfica e o uso de filmes. A projeção fotográfica é ensaiada pela primeira vez em 1924 na representação de Bandeiras. Nos dois lados do palco havia telas de projeção sobre as quais apareciam, durante o prólogo, as fotografias das personagens que estavam sendo caracterizadas antes da ação. Durante a peça as telas tinham a função de interligar diferentes concepções. 0 mesmo recurso é usado em Revista vermelha (1924) e N ostalgia (1928), para a qual Heartfield concebe uma projeção a partir de material fotográfico cedido.

O uso de filmes como ampliação e aprimoramento da projeção fotográfica é bem mais constante, como atestam Apesar de tudo! (1925), 0 dilúvio (1926), Vela no horizonte, Navio embriagado, Tormenta sobre a terra de Deus (1927), O ba, estamos vivendo! (1927), Rasputine (1927-1928), As aventuras do bravo soldado Schwejk (1927-1928), Conjuntura (1928).

No caso de Apesar de tudo!, que é uma montagem de discursos, textosjornalísticos, conclamações, folhetos, fotografias efilmes da guerra e da revolução de novembro, de personagens e cenas históricas, as fitas de cinema deveriam ligar-se de maneira orgânica aos fatos que estavam se desenrolando no palco. 0 cenário criado por Heartfield é extremamente sóbrio para poder real çar a função dos filmes e das fotografias projetadas, concebidos como documentos que deviam ter sobre o público "influência muito maior que a de cem relatórios" ${ }^{39}$. Escrita por Piscator e Felix Gasbarra, a peça inspira-se numa frase pronunciada por Liebknecht pouco antes de seu assassinato em janeiro de 1919: com ela, o líder espartaquista afirmava sua crença no prosseguimento da revolução, apesar das derrotas sofridas pelos comunistas em 1919. A ação acompanha a vida do político entre o começo da Primeira Guerra M undial e sua morte durante a repressão à Liga Spartacus levada a cabo pelo governo Ebert entre fins de novembro de 1918 e meados de janeiro de 1919.

O intercâmbio constante entre cenas filmadas e ação dramática provoca aquele que Piscator denomina "momento de surpresa", graças ao qual sua concepção cênica pode ser colocada na base do teatro épi- 
co de Brecht. Como o próprio Brecht reconhece num artigo dedicado a Piscator, o uso do cinema acaba por conferir à cena dramática uma importância decisiva em pelo menos dois aspectos. 0 espectador tem condições de observar por si determinados processos que fundamentam as decisões tomadas pelas personagens, podendo julgá-las sem ter que passar obrigatoriamente pelo filtro dos intérpretes. As personagens, por sua vez, podem expressar-se livremente, pois não têm o dever de informar objetivamente o espectador. Além disso, o dramaturgo destaca como elemento determinante nessa concepção teatral "a força incalculável" conferida à expressão falada pela existência de um "fundo real" (cinema e fotografia), que toma a si a tarefa de expor os fatos da atualidade. ${ }^{40}$

Nessa convergência de documento e arte, nessa opção por "deixar que os fatos crus falem por si próprios" - como escreveu Leo Lania, um dos colaboradores de Piscator, a propósito de Bandeiras ${ }^{41}-$, um conceito-chave é, sem dúvida, o de montagem. Se não é fácil determinar o fluxo de intercâmbios entre Heartfield e Piscator, é, porém, possível reportar tais interesses e atitudes a um panorama cultural mais amplo, no qual a problemática da montagem estava sendo amplamente discutida.

De proveniência industrial - o termo M onteur designa em alemão o operário que trabal ha na indústria automobilística e o eletricista, entre outros - , a palavra montagem é associada desde logo à cinematografia. Em sentido técnico nenhum filme dispensa o princípio da montagem: como lembra Tretyakov, a seqüência mecânica dos fotogramas cria o movimento; os movimentos combinados estão na base do desenvolvimento da idéia dramática, cabendo à montagem adaptar a dinâmica do fato ao enredo. ${ }^{42} \mathrm{~N}$ ão é, contudo, nessa acepção mais simples que a idéia de montagem é discutida nos Estados U nidos e na Europa entre 1910 e 1930. Bastaria lembrar as propostas de David Griffith (montagem paralela), V sevolod Pudovkin (combinação de planos formando um bloco seqüencial que permite criar um efeito de tensão e significação), Sergei Eisenstein (articulação de descontinuidades e oposições), que pretendem alcançar respectivamente a tensão ou o contraste entre histórias narradas paralelamente, a produção de uma idéia graças 
à ligação de planos em série e a introdução de uma fissura na continuidade da narrativa por intermédio do conflito de duas imagens entre si. ${ }^{33}$

Por romper a unidade da narrativa e por buscar a criação de uma "imagem invisível" graças à "sucessão rápida, alternada, de imagens visíveis", como acontece em Outubro (1928), no qual o tiro disparado pela arma do metral hador é produzido pela montagem (não pela filmagem), ${ }^{44} 0$ cinema de Eisenstein é associado às fotomontagens de H eartfield, das quais seria um elemento deflagrador. Trata-se de uma relação mais complexa, como demonstram John Willett e D ouglas Kahn, quando chamam a atenção para o papel pioneiro dos representantes do Dadaísmo alemão em relação a al guns postulados da vanguarda soviética. 0 marco do início das relações culturais entre Berlim e M oscou é representado pela exposição de arte russa organizada pela galeria Van Diemen de Berlim em outubro de 1922. A exposição é, em parte, conseqüência do empenho de Willi M ünzenberg, que trabalhava no setor de propaganda do Partido Comunista Alemão e que havia criado o Socorro O perário Internacional com o intuito de aliviar a carestia que assolava a União Soviética pós-revolucionária. A partir de 1922 Berlim torna-se o eixo do intercâmbio cultural dos artistas soviéticos com o Ocidente, e nesse intercâmbio Willett e Kahn destacam o papel de H eartfield, Grosz e H ausmann, que teriam estimulado as pesquisas de Rodtchenko e El Lissitzky, bem como a idéia da "montagem de atrações", que Eisenstein aplica ao teatro pouco antes de dedicar-se ao cinema. ${ }^{45}$

O próprio Eisenstein, no artigo "M ontagem de atrações" (1923), cita "o armazém de imagens de Grosz" e"os elementos de fotoilustração de Rodtchenko" entre as fontes de uma idéia de espetáculo que desejava abolir o teatro como instituição figurativo-narrativa. A "atração" resultava da redução dos elementos do dispositivo teatral ao estatuto de unidade molecular. A montagem das diferentes atrações a exemplo do cinema, do circo, do music-hall - tornava-se o elemento principal do espetáculo. Graças à utilização de "artifícios reais" (manifestos, exibidos) e "fragmentos figurativos", Eisenstein propunha um trabalho de montagem quelevava em conta os vários elementos do dis- 
positivo teatral libertos de uma seqüencialidadenarrativa e, logo, al heios aos antigos vínculos hierárquicos da ação dramática. ${ }^{46}$

Quando passa a dedicar-se ao cinema, Eisenstein deixa logo de lado a lógica de agregação dos objetos (próxima da colagem e da fotomontagem) em prol de uma “'imagem' não figurada, que procede de uma expressão simbólica 'liberada dos condicionamentos tradicionais' ( narrativa, lógica empírica dos fatos, representação) , que recorre à associação livre para promover um pensamento abstrato transposto para a tela" graças a uma colisão de conceitos. ${ }^{47}$

Se através de um filme como 0 encouraçado Potemkin (1925), que faz sucesso na Alemanha antes de na União Soviética, Eisenstein permite trazer de volta a Berlim o conceito de montagem numa outra versão, não é esta a única possi bilidade de narrativa não linear com que que H eartfield tem de se defrontar. Na segunda metade dos anos 20 desenvolve-se na Alemanha um novo gênero de filme, que Kracauer considera "a mais pura expressão da N ova O bjetividade no cinema". São os filmes de corte transversal, interessados em registrar a vida real por intermédio da reunião de um conjunto de tomadas documentais, como atestam Berlim: sinfonia de uma cidade (Walter Ruttmann, 1927), 0 mercado de Wittenbergplatz (Wilfried Basse, 1929), Gente no domingo ( realização de seis cineastas, 1930), A Alemanha ontem e hoje (Basse, 1934). Uma vez que era possível utilizar material preexistente, havia filmes de corte transversal de baixo custo, como Em volta do amor (1929), produzido pela UFA a partir de episódios românticos de vel has fitas, e M ilagres do universo (1929), feito a partir de películas dedicadas a expedições. 0 uso de materiais preexistentes permitia, por vezes, a configuração de um novo ponto de vista. É o caso de um filme apresentado uma única vez em 1928 e que acabou sendo censurado: em virtude da nova disposição que Ihes foi dada, as cenas originais produzidas pela UFA "perderam repentinamente sua inocência política e assumiram um caráter inflamado", como sublinha Béla Balázs. ${ }^{48}$

A possibilidade de anular as relações convencionais entre os elementos de uma composição graças à associação de partes e detalhes e de criar configurações inusitadas ${ }^{49}$ não é exclusiva do cinema. 0 princípio da montagem faz-se presente também na literatura das primei- 
ras décadas do século XX, e um exemplo paradigmático de narrativa fragmentada localiza-se justamente na Alemanha deWeimar: o romance Berlim Alexanderplatz, de autoria de Alfred Döblin (1929).

Fautor de um estilo cinematográfico desde 1913 - decorrente de uma leitura crítica dos postulados futuristas e de uma intensa vivência urbana que o levava a defender a transposição para o plano literário daquela seqüência rápida e contínua de imagens que caracterizava a percepção do homem moderno - , em Berlim Alexanderplatz Döblin lança mão da montagem como um elemento paradigmático, que lhe permitiria criar um espaço textual anônimo, no qual se desenrola a história de Franz Biberkopf, e apresentar uma totalidade discursiva fragmentária, que confere ao enredo uma dimensão bem maior do quea exposição de um caso particular. Usando tanto textos literários quanto um farto material extraliterário (relatórios da Bolsa de Valores, publicações oficiais, anúncios, reclames, prospectos cinematográficos, cartas, estudos estatísticos, noticiários locais, boletins meteorológicos, itinerários de bondes, canções populares, etc.) , Döblin não só coloca em xeque a concepção tradicional de romance, como transforma o documento num elemento fundamental da criação literária. Por esse aspecto, Benjamin traça um paral elo entre o romance e a busca do autêntico acentuada pelo Dadaísmo e levada, por vezes, a cabo pelo cinema, denotando a existência de uma clara atitude antiexpressionista a partir de meados dos anos 20, vazada na volta ao concreto e na valorização da pesquisa sociológica e da reportagem..$^{50}$

É nesse clima de valorização de uma visão realista, em que a arte adquire freqüentemente uma função instrumental, que se insere a publicação de Alemanha, Alemanha acima de tudo (1929) , fruto da colaboração entre um pacifista-liberal (Kurt Tucholsky) e um comunista ( Heartfield). 0 texto de Tucholsky é ilustrado com fotografias selecionadas por H eartfield e com várias fotomontagens, cujo viés satírico e mordaz provoca não poucas críticas, a começar pela capa e pela contracapa. A capa apresenta uma cabeça disforme, de queixo gordo e recoberta por uma bandeira, envergando um capacete ao qual se sobrepõe uma cartola. A fusão da dimensão civil com a militar repete-se na caracterização do traje. De uma mancha negra, que desempenha a fun- 
ção de boca, sai o título do livro em letras pretas, brancas e vermel has que, associadas ao fundo amarelo da composição, retomam as cores da bandeira nacional. A contracapa é igualmente mordaz, ao apresentar uma visão simbólica da Alemanha como campo de batalha: um cacete levantado está emparelhado em perfeito equilíbrio com uma espada desembainhada virada para baixo. A provocação não se limita à capa, que acaba sofrendo censura por parte dos distribuidores: espalha-se pelas páginas do livro, atingindo o ponto mais crítico numa fotomontagem acrescentada no último momento, sem o conhecimento de Tucholsky, Feras ol ham para você. N ela H eartfield representa oito militares aposentados, tendo como fontedeinspiração um livro sobreanimais que fizera sucesso em $1928 .^{51}$

A atitude de Heartfield em Alemanha, Alemanha acima de tudo - sátira mordaz contra o chovinismo, o fascismo e uma sociedade parasitária, nos dizeres de Tretyakov ${ }^{52}$ - não pode ser dissociada de sua militância política nas fileiras do Partido Comunista Alemão desdefins de 1918. Se a concepção das capas para a editora M alik traz claros índices de seu credo político - quer pelo papel privilegiado outorgado à imagem fotográfica, quer pelo uso freqüente de toques vermelhos - , H eartfield torna ainda mais explícita sua militância em trabalhos como a fotomontagem Dez anos depois: pais e filhos (1924), a capa de Lugar aos trabalhadores! (1924) e o cartaz para as eleições parlamentares de maio de 1928.

Dez anos depois: pais e filhos é concebida para a vitrine da livraria da editora M alik. Ao evocar os dez anos transcorridos desde o início da Primeira Guerra M undial, o artista sobrepõe a figura do general $H$ indenburg a um exército de esqueletos. A seus pés desfila um novo exército, integrado por crianças em uniforme militar..$^{53} \mathrm{~A}$ composição era ladeada na vitrine por éditos militares, carteiras de racionamento, folhetos e documentos do período bélico, tendo provocado violentos protestos.

Lugar aos trabalhadores!, anuário publicado pela Malik em 1924, traz depoimentos políticos de Tucholsky, Rosa Luxemburg eWittfogel, entre outros. Para sublinhar o caráter engajado da publicação, H eartfield concebe uma capa articulada em quatro fileiras de fotografias que 
representavam cenas revolucionárias, imitando um rolo de película cinematográfica. Acima e abaixo das imagens estão inscritas al gumas frases em caracteres brancos sobre um fundo vermelho: "As revoluções são as locomotivas da história”; "O s filósofos apenas interpretaram 0 mundo de maneira diferente. M as depende de você modificá-lo" (Karl M arx); "As idéias dominantes de uma época são sempre as idéias da classe dominante". Contra o fundo neutro das imagens ( preto e branco) destaca-se a inscrição do título em letras vermelhas ocupando as duas primeiras fileiras à direita, o que gera uma certa semelhança entre o anuário e um cartaz político.

0 ativismo político faz-se novamente presente em Vote Lista 5, para o qual H eartfield projeta uma imagem de apelo imediato: a fotografia de uma mão aberta sob a qual se destaca em vermelho o número 5 repetido duas vezes com os seguintes dizeres em letras góticas: “A mão tem 5 dedos/com os 5 pode-secapturar o inimigo/Vote Lista 5/Partido Comunista!"

Em 1930, Heartfield dá início ao trabalho que firmou sua reputação de fotomontador: começa a colaborar com uma revista do Partido Comunista Alemão, Arbeiter Illustrierte Zeitung. Para compreender a importância dessa nova etapa na carreira do artista, é necessário lembrar o papel exercido pela imprensa na Alemanha de Weimar, cuja idade de ouro se situa entre 1927 e 1929. Berlim, chamada por Pascal Huynh de "cidade-jornal", agrupava $26 \%$ da produção total da imprensa alemã. Contava com 147 jornais em 1927, al cançando a cifra de2.633 publicações entre diários e revistas no ano seguinte. Berliner Lokal-Anzeiger, D er Tag, Berliner Nacht-Ausgabe, Berliner Tageblatt e Die Vossiche Zeitung eram os principais órgãos da cidade. Os partidos políticos dispunham também de publicações próprias: Vorwärts e Tempo (Partido Social-Democrata), Die Rote Fahne eDieWelt am Abend (Partido Comunista), Der Völkische Beabachter (Partido Nacional-Socialista). O jornal mais popular era de tendência liberal, Berliner Börsen Courier. A esquerda dispunha também de um semanário, D ie Weltbühne - entre cujos colaboradores estava Kurt Tucholsky - , queexercia uma grande influência intelectual em Berlim, embora tivesse uma tiragem restrita de 16.000 exemplares para o resto do país. ${ }^{54}$ 
É nesse ambiente cultural que se insere a fundação de AIZ. A revista tem seu início em Russland im Bild, publicação mensal fundada em 1921 por iniciativa do Socorro O perário Internacional, com uma tiragem de 100.000 exemplares. Em 1923-1924 transforma-seem H ammer und Sichel e, posteriormente, em Arbeiter Illustrierte, passando a ser uma publicação quinzenal (1925). Alcança uma tiragem de 220.000 exemplares em 1927: passa a ser semanal sob o nomedeA-I-Z. Em 1931 alcança 500.000 exemplares e sofre uma nova transformação no nome, que passa a ser grafado AIZ.

SeAIZ não competia numericamente com o Berliner Illustrierte Zeitung (mais de dois milhões de exemplares no começo da década de 30), tratava-se, contudo, de um empreendimento que alcançava um público significativo, integrado por operários, funcionários, donas de casa, profissionais liberais, autônomos e jovens, entre outros. Sua distribuição, além da Alemanha, abarcava T checoslováquia, Suíça e Áustria, mas há notícias de que chegou a alcançar países como U ruguai, Canadá, Austrália e Japão.

A revista, caracterizada por um projeto gráfico inovador, era composta de várias seções: artigos sobre política nacional e internacional; temas de "interesse humano"; romances publicados em capítulos; poesia; uma página destinada à mulher ou à criança; uma página de piadas e palavras cruzadas; uma página dedicada a uma produção artística, geralmente a cargo de Heartfield, mas podendo contar com a colaboração de outros artistas, como a fotógrafa italiana Tina M odotti e a gravadora Käthe Kollwitz. AIZ chega a organizar um concurso de fotomontagens entre os leitores e divulga notícias sobre cursos práticos que H eartfield ministrava em associações operárias para propagar a técnica. ${ }^{55}$

Essas iniciativas não são consensuais no âmbito da esquerda. Franz Höllering, queaprecia o uso da fotomontagem em H eartfield, não aconselha sua prática ao operariado por temer a difusão de "um diletantismo da pior espécie". Confrontado com a rápida difusão da técnica e com sua apropriação pela burguesia, Höllering exorta o trabalhador a dedicar-seà fotografia pura, sem perder tempo com pretensões artísticas descabidas, que o distanciariam da "grande idéia do socialismo".56 
Mais complexo é o juízo de Durus (Alfred Kemény), membro do Partido ComunistaAlemão desde 1923. Num artigo publicado em 1931, o autor estabelece uma diferença fundamental entre a fotomontagem burguesa e a fotomontagem revolucionária. Se ambas têm como princípio a recombinação de "partes da realidade", não se confundem, porém, entre si. A fotomontagem burguesa falsifica a realidade social como um todo, usando a objetividade da fotografia para disfarçar o processo e para dar a impressão de que o que está sendo apresentado é a "verdadeira realidade". A fotomontagem revolucionária, ao contrário, estrutura dial eticamente os detal hes fotográficos, evidenciando as relações e as contradições da realidade social. Se H eartfield e N ilgreen (Oscar Nerlinger) se inscrevem nessa vertente, isso não significa quea fotomontagem possa ser usada pelos trabalhadores, pois ela representa "uma distração da luta de classe revolucionária e das tarefas essenciais do fotógrafo proletário como repórter revolucionário". O ceticismo do artigo de 1931 sobre as reais possibilidades políticas da fotomontagem cede lugar a uma visão claramente positiva no ano seguinte. M otivado pelas realizações de Heartfield para AIZ, D urus coloca-as entre "as criações satíricas mais significativas do nosso tempo," e não deixa de elogiar as iniciativas tomadas pela Liga de Artistas Internacionais e pelo movimento dos fotógrafos proletários, que haviam feito da fotomontagem "uma arma na prática diária da luta de classe".,57

A tarefa que Durus confia à fotomontagem - revelar "relações, oposições, transições e intersecções da realidade social" temente derivada da observação dos trabal hos que H eartfield estava divulgando em AIZ. Na primeira fotomontagem realizada para a revista e publicada na edição de 9 de fevereiro de 1930, o artista ataca de uma só vez a imprensa e o Partido Social-Democrata. A imagem mostra uma cabeça em forma de repolho, embrulhada nas páginas de dois jornais do Partido Social-D emocrata - Tempo e Vorwärts - , acompanhada pela legenda: “Q uem lê os jornais burgueses tornar-se-á cego e surdo. Abaixo as vendas que aturdem."

Os dois alvos não são casuais. Heartfield, de fato, tem como objetivo propor uma releitura crítica não só da realidade, mas dos mecanismos de conhecimento da realidade através dos meios de comunica- 
ção de massa. N esse contexto, a fotografia desempenha um papel específico e determinante, se for lembrada a crítica que Walter Benjamin Ihe dirigia nos anos 30. I magem associada ao poder de transfiguração do real emanado do aparato técnico, a fotografia tem a capacidade de embelezar o mundo, transformando "num objeto de gozo a própria miséria, representando-a de maneira aperfeiçoada, perfeitamente na moda". Se Benjamin reconhece uma função importante à fotografia colocar à disposição das massas conteúdos aos quais antes não tinha acesso - , não deixa, contudo, de assinalar a manipulação de seus produtos, que são reelaborados de acordo com a moda para que não haja qualquer transformação do mundo.

0 autor acreditava que seria possível conferir uma função política à fotografia; por isso solicitava que o fotógrafo dotasse sua imagem de um comentário escrito, capaz de resgatá-la do desgaste da moda e de atribuir-Ihe "um valor de uso revolucionário". ${ }^{59}$ Se isso não é propiciado pela imprensa em geral, está, porém, no centro das preocupações de Heartfield, que resgata o caráter político da imagem técnica no momento em que testa com suas montagens o poder de persuasão da fotografia. A transfiguração perseguida por ele, longe de confirmar o discurso dominante, forneceelementos para detectar o processo ideológico de construção da notícia e, para tanto, não dispensa a associação da imagem a um texto, cuja função é a de reforçar a contranotícia que se configura a partir da montagem fotográfica. Muitas vezes, os textos que acompanham as fotomontagens de AIZ são de autoria do irmão Wieland que, ao que parece, o ajudou na criação de algumas imagens, conforme se lêem John H eartfield: art and mass media..$^{60}$

A fotomontagem de 9 de fevereiro de 1930 é um exemplo claro de contranotícia. Heartfield lembra nela o papel desempenhado por Tempo e Vorwärts nas elei ções de 1928 e a coalizão da social-democracia com os partidos burgueses, da qual resultou a marginalização dos comunistas. 0 episódio é esclarecido no texto situado à direita da imagem, em que há uma tomada de posição contra a imprensa comunista por parte de alguém que espera por um messias e que nada quer com a política.

A imprensa partidária volta a estar no centro das atenções de 
H eartfield em Saudações fraternas do PSD (fevereiro de 1931), na qual fragmentos deartigos deVorwärts emolduram o cadáver deKarl Liebknecht, a fim de lembrar a responsabilidade do partido (através do governo Ebert) no assassinato do líder espartaquista. 0 mote da composição está num trecho de um artigo do Berliner Tageblatt (15 de fevereiro), no qual era dado destaque ao papel do Partido Social-Democrata na política nacional desde a proclamação da República: “É necessário ter uma predisposição particular ao suicídio se se esquece que a Social-Democracia foi muito necessária no período do Espartaquismo e se não se considera que, provavelmente, ela será ainda mais necessária algum dia."

0 ataque mais virulento contra o Partido Social-D emocrata localiza-se em duas imagens igualmente produzidas em 1931. Na primeira, O congresso da crise do PSD ( 15 de junho), Heartfield toma como ponto de partida um discurso do deputado Fritz Tarnow. Para entender a escolha do artista, é necessário lembrar que, durante a República de Weimar, o Partido Social-D emocrata tentava conciliar instâncias marxistas e instâncias monopolistas, num panorama caracterizado por profundas contradições econômicas no interior da aliança que detinha o poder, e pelo surgimento de uma direita autoritária. É essa situação que Tarnow enfrenta no discurso proferido no Congresso de Leipzig. Cabia ao PSD desempenhar um duplo papel: ser o médico que procurava curar o capitalismo e o herdeiro interessado em tomar imediatamente posse de sua herança. ${ }^{61}$

H eartfield elimina da fotomontagem a questão da herança para concentrar-se na aliança entre socialismo e capitalismo, lançando mão das metáforas médicas utilizadas por Tarnow. Uma vez que o capitalismo é representado por um tigre, os médicos do discurso transformamse em veterinários. A transcrição de uma frase textual do deputado "A social-democracia não deseja a ruína do capitalismo. Como um médico, procura curar e melhorar" - éacompanhada de uma legenda satírica - "Os veterinários de Leipzig: evidentemente extraíremos os dentes do tigre, mas antes devemos alimentá-lo e curá-lo."

Para tornar ainda mais enfática sua crítica à política social-democrata, Heartfield cria um contraste entre imagem e texto. 0 tigre - em 
cujo focinho aberto deve-se ver uma referência a Tarnow como representante dos "veterinários" - não só goza de boa saúde como demonstra ser particularmente agressivo. 0 recurso à imagem do tigre é decorrência de uma situação concreta: após a crise inflacionária de 1923, o capitalismo monopolista alemão passa por um processo de aceleração, acompanhado de um agravamento das contradições econômicas internas das classes que estavam no poder. Se havia um estado de tensão entre o grande capital e a propriedade fundiária, entre o grande e o médio capital, a maior contradição residia na fusão que estava sendo realizada entre o capital bancário e o capital industrial. É dela que surge o grande capital financeiro, caracterizado pelo predomínio do banco sobre a indústria. A instabilidade, que é a marca distintiva do período imediatamenteanterior à conquista do poder por parte do Nazismo, é atribuída por N icos Poulantzas ao fato de o grande capital não conseguir estabelecer de imediato a própria hegemonia política. 0 que caracteriza, de fato, o governo do chanceler Heinrich Brüning (19301932) é a manifestação de uma incapacidade hegemônica: nenhum elemento do bloco dirigente consegue impor uma política capaz de representar a um só tempo o interesse comum einteresses específicos de cada fração. A aliança do grande capital com a social-democracia, que representava os interesses do médio capital, fracassa em pouco tempo, o que gera um clima de luta aberta entre os vários integrantes do bloco dominante. ${ }^{62}$

É essa situação de tensão, na qual a social-democracia desempenha um papel cada vez mais reformista em relação às classes trabal hadoras, que H eartfield condensa em sua composição. A relação do PSD com os trabalhadores pode ser detectada a partir da qualificação que o artista dá a Tarnow: não deputado, mas presidente da Federação dos M adereiros. Desse modo, Tarnow aparece na fotomontagem como um agente da "aristocracia do trabalho" nas fileiras do partido. "Aristocracia do trabalho" é a designação dada a uma camada mais al ta da classe trabalhadora que controla os partidos para manter os próprios privilégios. O conceito fora usado por Lênin para explicar a confluência dos socialistas com as burguesias nacionais por ocasião da Primeira Guerra Mundial. No período de Weimar, os dirigentes social-democratas 
destacavam-se por ter adotado um modo de vida burguês, bem distante das bases partidárias. ${ }^{63}$

A última máxima do PSD: "Abaixo o M arxismo!" éa segunda imagem inspirada pelo Congresso de Leipzig. No centro da cena concebida por Heartfield, vê-seKarl M arx, quetraz debaixo do braço um exemplar do jornal do Partido Comunista Alemão, Die Rote Fahne. À sua esquerda, três policiais estão prestes a prendêlo, dirigidos pelo chefe da Polícia de Berlim, Karl Zörgiebel, que fecha a composição à direita. O significado da cena deve ser buscado nas legendas: em letras miúdas é reportado um trecho do discurso de Sollmann-Köln no congresso de maio-junho, que condena o pensamento de M arx por reacionário. Em letras maiores é explicitado o subdiscurso do PSD: "O Senhor está preso por ser um falso profeta, Senhor Karl M arx - não são apenas nossas correntes que temos que perder, mas também nossas comedorias e nossas poltronas ministeriais." Se mais uma vez é evidente o afastamento do PSD de suas primeiras diretrizes ideológicas, a presença de Zörgiebel merece um esclarecimento ulterior: em 10 de maio de 1929, ele comandara a repressão a uma manifestação dos comunistas, que fora proibida pelo governo social-democratra da Prússia. D ela resultaram trinta e três mortos, uma centena de feridos e mil prisões. A presença de Zörgi ebel na fotomontagem simboliza, pois, a manutenção de uma política repressiva, pela qual o PSD é considerado diretamente responsável, mesmo que fosse para "não fornecer qualquer pretexto" aos nacional-socialistas. ${ }^{64}$

A atitude de Heartfield para com os social-democratas deve ser analisada à luz da política adotada pelo partido desde o fim do império guilhermino. 0 primeiro presidente da República de Weimar, Friedrich Ebert, que pertencia aos quadros do partido, quando ainda chanceler do Império, estabelece um pacto com o general Groesner, que deveria garantir a manutenção da ordem e o combate ao bolchevismo após a partida de Guilherme II para a Holanda. O Partido Comunista, nascido de uma dissidência contra as orientações do Partido SocialDemocrata, não lhe imputava apenas a traição de novembro de 1918. Imputava-Ihe também a condição de "social-traidor" em 1914, por ter aderido à Primeira Guerra M undial; e de "social-fascista” em 1923, por 
ter esmagado o governo de unidade formado na Saxônia depois de uma ação entre as assembléias regionais comunistas e social-democratas. Os incidentes de 1ํ de maio de 1929 são mais um episódio na luta entre social-democratas e comunistas, que representavam duas diretrizes totalmente opostas - reformista e revolucionária - no âmbito do movimento operário. Em termos sindicais a situação é igualmente tensa: em 1929 os comunistas abandonam a União Geral dos Sindicatose fundam a O posição Sindical Revolucionária. Contando com o apoio de mais de $20 \%$ do eleitorado, o PSD detinha um poder de fato, não só em virtude de sua tradição, mas também pela estratégia de compromisso praticada por seus dirigentes, inclusive em relação ao avanço nazista, e pelo apoio dado ao governo, que o leva a adotar uma política burguesa em relação à classe operária. ${ }^{65}$

Se essa relação tensa com os social-democratas é a tônica de várias fotomontagens de $A I Z$, o alvo principal de Heartfield é, porém, 0 Nazismo, denunciado em seus vários aspectos, a começar pelas relações com a al ta finança. I sso fica claro em Sob esse si gno vocês serão traídos e vendidos ( 3 de junho de 1932), na qual a suástica formada por moedas remete à organização de células nazistas nas fábricas para obstaculizar o avanço do marxismo; em Adolf, o Super-homem: traga ouro e fala disparates (17 de julho de 1932), representação de Hitler como porta-voz do capitalismo alemão; em 0 sentido da saudação hitleriana: o pequeno homem pede grandes donativos (16 de outubro de 1932), feita a partir da apropriação de uma fotografia jornalística que apresentava o Führer participando de uma manifestação política, (ver imagens no fim deste capítulo). O lema do Nazismo - “M ilhões estão atrás de mim" - recebe uma contral eitura de H eartfield. Os milhões de alemães, que formavam a base de sustentação do Nazismo, convertem-se nos milhões que o capitalismo monopolista alemão dá a H itler para a manutenção de sua política. 0 estranhamento provocado pela contraposição entre o tamanho diminuto de Hitler e a representação gigantesca do capitalista é reforçado pelo uso de um recurso pictórico: a aposição de um anel brilhante na mão que entrega o dinheiro.

As mais diversas atitu des dos nazistas passam pelo crivo de Heartfield. Em M imetismo (19 de abril de 1934), o artista apresenta Joseph 
Goebbels, ministro da Propaganda e da Informação do Terceiro Reich, em pose de barbeiro, enquanto disfarça Hitler de M arx graças à colocação de uma barba basta. À esquerda, debaixo do título da fotomontagem, lê-se uma informação que explica o significado da encenação: uma vez que as idéias nacional-socialistas não tinham penetração na classe operária, Goebbels havia convencido Hitler a passar-se por M arx quando se dirigia aos trabalhadores. À direita, há uma nota jornalística de 8 de abril que faz referência a uma transformação que seria introduzida na medal ha comemorativa do 1 ㅇdemaio para ganhar as simpatias dos trabalhadores hostis ao regime: ao lado do busto de Goethe e da águia com a cruz gamada seriam colocados os símbolos bolchevistas da foice e do martelo.

Goebbels havia sido protagonista de uma outra fotomontagem, Da luz para a noite (19 de maio de 1933), dedicada ao auto-de-fé de 10 de maio, do qual resultou a queima de vinte mil livros numa cerimônia solene organizada pelo Comitê de Ação contra o Espírito Antialemão. A cerimônia principal, comandada pelo ministro, teve lugar em Berlim, associada a manifestações similares em todas as ci dades universitárias do país. 0 jogo de palavras proposto pelo título da composição inverte a simbologia do ato, ao qual Goebbels havia atribuído vários significados - destruição do passado pelas chamas, surgimento do futuro das chamas dos corações dos al emães, luz iluminando o juramento nazista e abrindo caminho para a constituição de um espírito verdadeiramente nacional ${ }^{66}-$, ao denunciar a ditadura cultural que estava sendo implantada em nome da união do Reich.

O episódio do incêndio do Parlamento (27 de fevereiro de 1933), que foi determinante na ascensão de Hitler ao poder, é evocado em Goering, o carrasco do Terceiro Reich ( 14 de setembro). A fotomontagem - capa do número especial dedicado por AIZ ao processo contra os (supostos) responsáveis pelo incêndio que estava tendo lugar em Leipzig - caracteriza-se como uma contra-informação, pois imputa a Hermann Goering, presidente do Parlamento, a instigação do ato. A figura do político, envergando um uniforme de marechal, coberto na parte inferior por um avental de açougueiro, e trazendo um machado na mão esquerda, domina a composição, em cujo fundo se vêa cena 
do incêndio. A imagem de Goering chama a atenção por várias particularidades: pel o desequilíbrio evidente entre cabeça e corpo; pelo tratamento realista das manchas de sangue apostas com pincel no final da fotocomposição; pela semelhança com o quadro de Otto Dix, Os açougueiros (1920), ${ }^{67}$ em que a figura humana é substituída por um suíno. 0 rosto contorcido do presidente do Parlamento não deixa delembrar a expressão que H eartfield havia atribuído à hiena capitalista em 1932 (Guerra e cadáveres: a última esperança dos ricos). Para evitar a suspeita de qualquer manipulação há um esclarecimento na fotomontagem: o rosto de Goering fora extraído de uma fotografia original e não sofrera retoques. $\mathrm{H}$ eartfield, de fato, utiliza na obra duas imagens derivadas da imprensa (rosto e camisa) ao lado de imagens preparadas de propósito (braços, avental, machado), ${ }^{68}$ o que explica a desproporção da figura de Goering, à qual pode ser atribuído o significado simbólico da violência cega.

O caráter violento do Nazismo ganha força paradigmática em Irmãos idênticos, assassinos idênticos (2 de novembro de 1933), motivada pela entrega do punhal de honra do Partido Fascista italiano a Rudolf Hess, lugar-tenente de Hitler (13 de outubro) . A legenda não deixa dúvidas sobre as intenções críticas da imagem: "O camisa-negra ao camisa-parda: 'O punhal Ihe é devido. Você me superou no assassinato'." Heartfiel recria o episódio de maneira indireta, pois coloca em cena Julius Streicher, editor da revista anti-semita Der Stürmer. Streicher pisa impassivelmente uma vítima da violência, enquanto dirige o olhar para a homenagem que lhe está sendo prestada. Ao lado de material de imprensa, 0 artista lança mão de uma fotografia policial realizada em Stuttgart por volta de 1929 para representar a vítima. ${ }^{69} \mathrm{O}$ recurso à pintura faz-se presente novamente nas gotas de sangue que pingam do punhal, conferindo um ar ainda mais brutal à cena.

Uma violência sutil emana, ao contrário, de Como na Idade M édia... assim no Terceiro Reich (31 de maio de 1934). Numa composição dominada pela busca de um apuro visual extremo e de um grande equilíbrio formal, H eartfield põe em paralelo uma escultura medieval, que representa um homem submetido à tortura na roda, e a imagem contemporânea de um homem preso à cruz gamada numa pose que suge- 
re um movimento rotatório. A associação pretendida étotalmenteconfiada ao poder das imagens, cuja montagem é realizada pela mente do espectador, uma vez que o artista propõe uma relação sutil entre forma e significado. O s elementos textuais limitam-se ao título enxuto e a uma pequena inscrição relativa ao lugar de proveniência da escultura medieval. Heartfield dispensa a costumeira divisão do texto em inscriptio (título) e subscriptio (explicação mais detal hada da cena), a qual aproxima suas fotomontagens da técnica do emblema, ${ }^{70}$ para criar uma imagem forte em sua atemporalidade, que não remete a nenhum episódio pontual para poder afirmar mais enfaticamente os aspectos repressores e violentos do regime.

O ba, a manteiga acabou! (19 de dezembro de 1935) é um exemplo el oqüente das possibilidades satíricas da fotomontagem. N um típico interior nazista - com suásticas adornando o papel de parede, a fotografia de Hitler em evidência, uma almofada comemorativa de H indenburg no sofá - , uma família reunida em volta da mesa é apresentada devorando peças de armamento. Heartfield, que não poupa nem mesmo um bebê e um cachorro do singular banquete, inspira-se num discurso militarista de Goering: “O ferro sempre produziu um país forte; a manteiga e a banha produziram, quando muito, um povo gordo." A caracterização da sala em que se passa a cena não deixa dúvidas sobre o papel desempenhado pela pequena e média burguesia na sustentação do regime, uma vez que essas camadas sociais eram conhecidas como "comedores de pão com manteiga". ${ }^{11}$

Para realizar suas montagens, Heartfield contava com a colaboração de Wolf Reiss, encarregado de realizar fotografias, quando necessário, e de tarefas como a revelação ea ampliação das imagens. Emboratrabal hassecom um vasto arquivo demateriais spreexistentes, 0 artista, em vários momentos, encarregava Reiss de real izar al guma imagem específica, que respondia a uma intenção particular. N ão raro, Reiss tinha como ponto de partida um esboço a lápis preparado por Heartfield, que, por não fotografar, confiava ao meio gráfico a explicitação visual de suas idéias. $O$ fato de poder contar com a colaboração de um fotógrafo permitia-Ihe, por vezes, realizar fotomontagens mais sofisticadas graças à técnica da sobreimpressão. O s resultados proporciona- 
dos por ela são mais unitários, uma vez que não há interrupções entre as várias partes da montagem, como pode acontecer quando o processo é realizado com tesoura e cola. A sobreimpressão pode também trazer à tona as realidades psíquicas mais recônditas, evidenciando o alter ego de um Hitler (Adolf, o Super-homem: traga ouro efala disparates), submetido a uma radiografia peculiar, ou de um M ussolini (0 rosto do fascismo para a brochura A Itália acorrentada, 1928), sob cuja efígie aflora uma caveira. ${ }^{72}$

Para enfatizar ainda mais o caráter de construção de suas imagens, Heartfield não dispensava um uso expressivo dos instrumentos gráficos. Recorria a intervenções pictóricas para acrescentar detalhes significativos que faltavam nas imagens originárias. Para obter efeitos realistas lançava mão do aerógrafo, que lhe permitia obter uma superfície unitária ou enfatizar características já presentes na imagem. É o que acontece em algumas representações de Goering: de constituição robusta, o estreito colaborador de Hitler étransformado, graças ao uso do aerógrafo, num verdadeiro balão em composições como A saudação da forca ( 21 de setembro de 1933) ${ }^{73}$ e Os nazistas brincam com o fogo (28 de fevereiro de 1935).

A virulência dos ataques ao Nazismo leva Heartfield e a redação deAIZ (transformada em Die Volks-Illustrierte em 1936 e, mais tarde, em VI) a buscarem refúgio em Praga em 1933. Na capital tcheca, onde permanece até 1938, o artista continua a produzir fotomontagens, nas quais Elio Grazioli detecta uma total identificação entre artee publicidade. Lançando mão de idéi as e soluções formais inovadoras, H eartfield propõe uma nova sintaxe, que faz de sua publicidade a verdadeira práxis da arte no sentido marxista do termo. ${ }^{74}$

Embora Grazioli faça referência a uma práxis artística de caráter marxista, não se pode deixar de lembrar quea recepção do trabal ho de Heartfield não é pacífica no âmbito da ideologia comunista. Em 1935, Aragon faz uma apresentação apaixonada de seu trabalho, que reconduz a um quadro político preciso: a revolução de novembro, a República deWeimar, o advento do N azismo eo exílio em Praga. M ergulhado nos acontecimentos contemporâneos, $\mathrm{H}$ eartfield confere significados ao que outrora fora concebido para surpreender, dando vida a uma 
verdadeira arte de massa. Protótipo e modelo do artista antifascista, Heartfield

sabe criar essas imagens que são a própria beleza de nosso tempo, porque elas são o próprio grito das massas, a tradução da luta das massas contra o carrasco moreno com a traquéia repleta de moedas. (...) Sua arte é uma arte que segue Lênin, porque é uma arma na luta revolucionária do proletariado. John H eartfield sabe hoje saudar a beleza. Porque fala pela enorme massa dos oprimidos de todo o mundo, eisso sem abaixar por um instante sequer o tom magnífico de sua voz, sem humilhar a poesia majestosa de sua imaginação colossal. Sem diminuir a qualidade de seu trabalho. D ono de uma técnica que inventou integralmente, nunca refreado na expressão de seu pensamento, tendo por pal eta todos os aspectos do mundo real, dominando plenamente as aparências, tem como único guia a dialética material ista, a realidade do movimento histórico, que traduz em preto ebranco com a raiva do combate. ${ }^{75}$

Se a avaliação deAragon é positiva, o mesmo não pode ser dito da visão que Georg Lukács apresenta da fotomontagem em 1938. M entor cultural do Partido ComunistaA lemão, o crítico, ao polemizar com Ernst Bloch sobre o significado e os alcances da arte moderna, localiza no procedimento da montagem o ponto máximo do movimento de desagregação da realidade. Seus argumentos não poderiam ser mais claros:

N aqueles casos em que a montagem, na sua forma original, como fotomontagem, pode ter um efeito chocante e, assim, simultaneamente de agitação, a sua influência deriva precisamente do fato de ela reunir, com um efei to de surpresa, fragmentos de realidade efetivamente díspares, isolados, arrancados do seu contexto. A boa fotomontagem tem o efeito de uma boa anedota. $M$ as, no momento em que esta relação unilateral - no caso da anedota, justificada e eficaz - se apresenta com a pretensão de representar artisticamente a realidade (mesmo quando esta é apreendida como o irreal), o contexto coeso (mesmo quando este é formulado como desconexão), a totalidade (mesmo quando esta foi vivida como caos), o resultado final não pode deixar de ser uma profunda mo- 
notonia. Os pormenores poderão brilhar com as mais variadas cores, mas o conjunto resulta num desconsolo de cinzento sobre cinzento, tal como a poça de água, que não deixa de ser de água suja, mesmo quando os seus componentes apresentam as cores mais diversas.

Esta monotonia é a conseqüência necessária do abandono do reflexo objetivo da realidade, do abandono do esforço artístico com vista a dar forma à diversidade e unidade, al tamente complexas, das mediações e da sua superação nas personagens. Pois este modo de sentir o mundo não admite nenhuma composição, nenhum crescen do e decrescendo, nenhuma estruturação a partir de dentro, da natureza real da vida artisticamente configurada. ${ }^{76}$

A avaliação de Lukács não pode ser dissociada da discussão sobre o Expressionismo, na qual se engajara desde a publicação de um ensaio em International Literatur (janeiro de 1934). A caracterização que fizera do Expressionismo como movimento baseado numa mitologia irracional, que tendia para o pseudo-ativismo, para o manifesto emotivo, para a retórica, é rechaçada por Ernst Bloch em 1938. 0 autor não só demonstra a leitura particular realizada por Lukács, como a reporta a um quadro mais geral de recusa da vanguarda em nome do princípio da unidade. D efensor da descontinuidade inerenteà montagem como um dos princípios fundamentais da arte moderna, Bloch não deixa de propor um paral elo entre $\mathrm{H}$ eartfield e o resgate da arte popular realizado pelo Expressionismo. É provavelmente tendo em mente esse paralelo - "Num nível mais baixo, a fotografia satírica de Heartfield estava tão próxima do povo que muitos intelectuais, depois disso, negaram ter algo em comum com a montagem"77 - que Lukács faz uma referência explícita à fotomontagem em sua réplica ao artigo de Bloch.

A concepção de realismo de Lukács, pautada pela oposição entre James J oyce (decadência artística) e Thomas M ann (realismo crítico verdadeiro), é reconhecida como restritiva por Brecht, que elabora uma proposta própria, na qual poderia caber a atividade de Heartfield. Num texto também datado de 1938, o dramaturgo define como atitude realista a apresentação do sistema da causalidade social; o desmascaramento das idéias dominantes como pertencentes aos que detêm o po- 
der; a adoção do ponto de vista do proletariado; a ênfase dada ao fator da evolução; a opção por uma postura concreta capaz de possibilitar a abstração. Distante dos cânones normativos de Lukács, Brecht propugna um realismo ampliado, que não se encerra numa forma de representação privilegiada:

Quem não estiver preso a preconceitos formais, sabe que a verdade pode ser ocultada de muitas maneiras, e que ela tem que ser dita de muitas maneiras; sabe que se pode despertar de muitos modos a indignação por condições inumanas, pela descrição direta, patética ou objetiva, pela narração de fábulas e parábolas, em anedotas, por exagero ou redução. ${ }^{78}$

As fotomontagens políticas de $\mathrm{H}$ eartfield respondem aos requisitos estabel ecidos por Brecht, pois colocam em cena "as verdadeiras forças motrizes da sociedade, que agem sob a superfície daquilo que éimediatamente visível". ${ }^{79}$ Bastaria atentar para o desvelamento do jogo de confusão entre aparência e realidade que está na base de fotomontagens como: Quem lê os jornais burgueses torna-se cego e surdo; 0 congresso da crise do PSD; Adolf, o Super-homem: traga ouro e fala disparates; 0 sentido da saudação hitleriana: o pequeno homem pede grandes donativos; M imetismo, entre outros. Ou para as diferentes modalidades estilísticas mobilizadas pelo artista para atingir seus objetivos, que vão da paródia ao registro cruento, da insinuação sutil à denúncia aberta.

Brecht, na realidade, apreciava o trabalho do "fotógrafo" H eartfield, como comprova um artigo escrito em 1938 para a revista Das Wort. D edicado ao músico Hanns Eisler, o artigo - que não chega a ser publicado - , inclui Heartfield entre os cinco artistas que tinham escolhido "estar do lado do Povo maltratado durante a guerra mundial e que a República não tinha indenizado". Os companheiros de H eartfield eram o próprio Brecht ("o escritor"), Grosz ("o desenhista"), Piscator ("o diretor") e Eissler ("o músico"). Embora só Eissler não encontrasse grandes resistências em relação ao próprio trabalho, os cinco artistas escolhidos como paradigmas por Brecht tinham algo em comum: eram todos donos de uma técnica "altamente aperfeiçoada, e suas obras se inscreviam numa evolução ininterrupta da própria arte. 
M esmo o cartazista, cuja arte era mais recente, continuava a tradição, em seu campo". ${ }^{80}$

A sintonia de Brecht com o trabalho de Heartfield não deita raízes apenas numa ideologia partilhada. 0 teatro épico e a fotomontagem integram um mesmo movimento cultural caracterizado pelo diálogo e pela aplicação crítica dos modernos instrumentos de comunicação. 0 teatro épico, cujo pressuposto básico é a apresentação de situações graças à interrupção da ação, não é alheio ao princípio da montagem, na qual o fragmento montado cria um intervalo no contexto em que é inserido. Além desse elemento em comum, é possível ampliar o paral elo entre Brecht e Heartfield e pensar numa leitura da fotomontagem a partir dos princípios estruturais do teatro épico. Tal como no teatro épico, a fotomontagem põe em xeque o princípio da ilusão: se naquele os intervalos contínuos, que interrompem a ação, levam o público a tomar uma posição em relação aos acontecimentos, nas fotomontagens de Heartfield isso é proporcionado pelo choque constante entre materiais de diferentes proveniências, que denunciam o caráter construído da imagem graças a desproporções, contravenções à norma perspéctica, etc. Teatro épico e fotomontagem, igualmente engajados na exposição do presente, podem ser considerados um laboratório no qual são colocados sob exame o homem, no caso do primeiro, e o universo da política e do jornalismo, no da segunda, de maneira a criar um estranhamento duradouro no público em relação às situações experimentadas no dia-a-dia. ${ }^{81}$

$\mathrm{N}$ ão é por ser político que o trabalho de H eartfield deixa de ter um elo profundo com a arte e com a própria história da arte. Como Aragon havia afirmado em 1935, o artista era um daqueles homens que, no início do século XX, haviam percebido o caráter efêmero da pintura e a necessidade de aderir a uma nova técnica, "mais conforme à nova vida, à humanidade de hoje". Essa técnica, que o escritor denomina colagem, permitia criticar a pintura graças ao uso da fotografia com novas finalidades poéticas. Por isso não se deveria ver em Heartfield apenas um artista de extração dadaísta e sim um artista plenamente inserido na história da pintura: 
Há naturezas-mortas de $\mathrm{H}$ eartfield, como aquela em que uma balança pende sob o peso de um revólver, ou a pasta de von Papen, como aquele andaime de cartas hitlerianas, que me fazem pensar invencivelmente em Chardin. Aqui, de maneira simples, graças às tesouras e ao pote de cola, 0 artista superou em termos de resultado o melhor daquilo que fora tentado pela arte moderna, com os cubistas, nesse caminho perdido do mistério no cotidiano. Simples objetos, como outrora em Cézanne as maçãs, e em Picasso o violão. M as aqui há, a mais, o sentido, e o sentido não desfigurou a beleza. ${ }^{22}$

O paralelo entre Heartfield ea arte moderna - notadamente Cézanne e Picasso - proposto por Aragon permite destacar um dos aspectos realmente inovadores da fotomontagem de H eartfield: uma nova concepção espacial em virtude da ruptura com a perspectiva renascentista, levada ao nível da fruição de massa. As sobreposições espaciais e as aproximações nem sempre lógicas de fragmentos de formato variado respondem a uma determinação de ordem perceptiva. Por viver numa metrópole como Berlim, o artista acaba concebendo 0 mundo "como uma montagem social e material que pode ser unificada só no plano dos sentidos, na anotação estética," ${ }^{33}$ o que explica a busca de uma visualidade múltipla e fragmentária, capaz de responder às novas si gnificações sociais e espaciais derivadas da experiência urbana. Ao optar pelo ritmo veloz da fotomontagem, Heartfield propõe um novo modo de fruição ao público: um olhar global, inclusivo, que capta, de maneira quase instantânea, os velhos significados das imagens de que o artista se apropria, e os novos significados derivados do processo de ressemantização ao qual as imagens foram submetidas. ${ }^{84}$

A fragmentação, que está na base da prática da fotomontagem, recebe uma leitura política por parte de Hubertus von Amelunxen. Os trabalhos de H eartfield colocariam em discussão a homogeneidade de fatura da superfície pictórica em termos visuais e narrativos para contrastar, por intermédio do fragmento, o totalitarismo fascista. 0 autor fornece um exemplo significativo da atitude política de $\mathrm{H}$ eartfield ao propor um confronto entre a apropriação de uma mesma imagem por ele e por Hannah Höch em 1930. Interessada em denunciar a impo- 
tência da mulher e sua condenação à passividade e à reprodução, H annah Höch sujeita a imagem-matriz deA mãe a uma grande transformação: corta-a sob o peito, fragmenta o corpo atéo torso, colore o fundo com tons claros de marrom e vermelho, coloca no rosto da mulher uma máscara africana recoberta de metal, que oculta o olho direito, acrescenta o olho esquerdo, provavelmente extraído de uma publicidade. Heartfield, ao contrário, faz de Fornecedora forçada de material humano (AIZ, março de 1930) uma tomada de posição contra a situação política do momento, ao sobrepor à imagem da mulher grávida aquela do cadáver de um jovem soldado e ao acompanhá-la com a legenda: "Ânimo! 0 Estado necessita de desempregados e de soldados!" 85

Tretyakov considera Fornecedora forçada de material humano o trabal ho mais dialético e mais racional de H eartfield, pois detecta um elemento temporal e não espacial na distância que separa o ventre inchado da operária grávida e o soldado morto. Considerando o cadáver como o fundo perspéctico da composição, o autor atribui-Ihe duas perspectivas: uma óptica e outra social. ${ }^{86}$ Embora Tretyakov fale em perspectiva, essa idéia deve ser revista, uma vez que a ligação entre a mulher e o cadáver é estabelecida por um artifício que rompe a homogeneidade da composição. 0 cadáver é revelado por um rasgo na imagem, mas não chega a contrastar o primeiro plano ao ser puxado para a frente pela cabeça da mulher. A grande forma ovoidal formada por ela contrapõe-se à figura diminuta do soldado, o que gera uma associação imediata entre procriação e morte numa sociedade militarista e capitalista.

A opção de Heartfield pela fotomontagem como sistema de significação insere-se num momento particular da história da fotografia, que Benjamin remete ao reclame e à associação, opondo-Ihe como atitudes legítimas o desmascaramento e a construção. 0 significado das atitudes consideradas legítimas é buscado pelo autor em Brecht, que propugna a construção contra a incapacidade de traduzir (criticamente) a realidade demonstrada pela imagem técnica:

Uma fotografia das fábricas Krupp ou AEG não diz quase nada sobre essas instituições. A realidade verdadeira resvalou na funcional. A reifica- 
ção das relações humanas, e logo por exemplo a fábrica, não remete mais às próprias relações. Trata-se pois, efetivamente, de construir algo, algo artificial e preparado. ${ }^{87}$

H eartfield constrói esse algo a que Brecht faz referência ao redirecionar o primeiro discurso das imagens de que lança mão. Inseridas no contexto determinado por ele, as imagens adquirem um novo significado, que não só explicita visualmente as tensões e as contradições da contemporaneidade, como dá a ver o espaço social como produto de uma construção. É o que Aragon havia percebido quando escreve que os fragmentos de fotografias usados pelo artista haviam começado "a significar" sob o impacto dos acontecimentos políticos contemporâneos. ${ }^{88}$

Para que o novo significado chegasse ao público leitor de maneira adequada, Heartfield busca uma comunicação direta, o que o leva a conjugar numa mesma composição o caráter ficcional da imagem recriada com efeitos realistas, que não só remetiam ao momento político, mas tinham a função de conferir credibilidade à mensagem. Por isso, não parece adequada para seu caso a leitura proposta por Rosalind Krauss para a fotomontagem dadaísta. De acordo com a autora norteamericana, um elemento determinante na práxis do grupo de Berlim é o sentido de espaçamento entre as imagens, o que transforma a página branca no meio que combina e separa os elementos recortados. A imagem fotográfica assim apresentada perde seu sentido de presença, negando a integridade aparente do real. Em vez de apresentar a realidade simultaneamente, a fotomontagem a apresenta seqüencialmente, deixando claro que o espectador se encontra diante de um "modo contaminado pela interpretação e pela significação, isto é, uma realidade dilatada pelos vaziose pelosbrancos, queconstituem as condiçõesformais preliminares à existência do signo".89

Não há espaços brancos ou vazios nas fotomontagens que H eartfield concebe para AIZ. O caráter compósito das imagens é fornecido por outrosíndices - falta de proporção, combinação de elementos heterogêneos, recurso à alegoria, situações improváveis, justaposições - , mas não pela presença de um intervalo físico entre um fragmento e 
outro. 0 intervalo buscado pelo artista é perceptivo: ele recompõe a realidade atomizada nos recortes de acordo com uma lógica nem sempre realista, mas nunca casual, para que suas imagens possam falar claramente da realidade política e social do próprio tempo.

FABRIS, A. Photomontage as a political function. História. São Paulo, v.22, n. 1, pp. 11 a 57, 2003.

ABSTRACT: The main feature of Berlin Dada is a project of political intervention, attuned to the ideological orientation of many of its members. Among them we can distinguish John Heartfield, who since 1915 looks for a language both modern and accessible to a mass audience. Therefore Heartfield makes use of photography in the bookcovers for M alik Verlag and is responsible for the development of political photomontage, published mainly in a magazine of the German Communist Party, Arbeiter IllustrierteZeitung.

KEYwOrD : Dada, photomontage, Nazism

\section{NOTAS}

${ }^{1}$ Investigação desenvolvida com uma Bolsa de Produtividadeem Pesquisa do CN Pq. ${ }^{2}$ Professora da Escola de Comunicações e Artes - ECA - USP - 05508-900 São Paulo - SP.

${ }^{3}$ FABRIS, A. Futurismo: uma poética da modernidade. São Paulo: Perspectiva: EDUSP, 1987, pp. 120-121.

${ }^{4}$ BARILLI, R. L'arte contemporanea: da Cézanne alle ultime tendenze. Milano: Feltrinelli, 1985, pp. 111-112.

${ }^{5}$ GO LDIN G, J. Le cubisme. Paris: Le Livre de Poche, 1968, p. 183. Também WESCHER, M . H istoria del collage: del cubismo a la actualidad. Barcelona: Gustavo Gili, 1977, não estabelece qualquer distinção entre colagem e papier collé.

${ }^{6}$ CO O PER, D. La época cubista. M adrid: Alianza Editorial, 1984, pp. 67, 205-210.

${ }^{7}$ ARAGON, L. Collages dans le roman et dans le film. In: Les collages. Paris: Hermann, 1980, p. 119; PERLOFF, M. The invention of collage. In: The futurist mo- 
ment: avant-garde, avant guerre, and the language of rupture. Chicago-London: The University of Chicago Press, 1986, p. 49.

${ }^{8}$ LAPLANTINE, F. \& N OUSS, A. Le métissage. Paris: Flammarion, 1997, pp. 106109.

${ }^{9}$ GOLDING, J. O p. cit., p. 183.

${ }^{10} \mathrm{COU}$ CH OT, E. La technologie dans l'art: de la photographie à la réalité virtuelle. Nîmes: Éditions Jacqueline Chambon, 1998, pp. 40-41.

${ }^{11}$ FRASCINA, F. Realismo e ideologia: uma introdução à semiótica e ao cubismo. In: HARRISON, C. et al. Primitivismo, cubismo, abstração: começo do século XX. São Paulo: Cosac \& Naify, 1998. pp. 162-163. Sobre a seleção de recortes de jornal em Picasso, vide também: PERLOFF, M. O p. cit., p. 50.

${ }^{12}$ BALDASSARI, A. Introduction. In: Picasso and photography: the dark mirror. Paris: Flammarion; H ouston: The M useum of FineArts, 1997, p. 9.

${ }^{13}$ RICHTER, H . Dadá: arte e antiarte. São Paulo: M artins Fontes, 1993, p. 157.

${ }^{14}$ H AUSM AN N, R. N ew painting and photomontage. In LIPPARD, L. (Org). Dadas on art. Englewood Cliffs: Prentice-Hall, 1971, p. 61.

${ }^{15}$ WESCHER, H . O p. cit., p. 114; PISCATOR, E. Teatro político. Rio de Janeiro: Civilização Brasileira, 1968, p. 226.

${ }^{16}$ SCH NEEDE, U. M . George Grosz: the artist in his society. Woodbury: Barron's, 1985, p. 23.

${ }^{17}$ HERZFELDE, W. John Heartfield, life and work. In: LIPPARD, L. (Org). O p. cit., p. 92. Vide também: KAH N, D. John H eartfield: art and mass media. N ew York: Tanam Press, 1985, p. 25.

${ }^{18}$ ADES, D. Photomontage. London: Thames \& Hudson, 1986, pp. 20-21; KAH N, D. Op. cit., p. 29.

${ }^{19}$ H AUSM AN N , R. Photomontage. In: GIROUD, M . (Org). Raoul Hausmann: "Je ne suis pas un photographe". Paris: Chêne, 1975, p. 59.

${ }^{20}$ KRIEGER, P. Paradoxo e poesia nas colagens de Hannah Höch. In H annah Höch 1889-1978: colagens. Stuttgart: Instituto de Relações Culturais com o Exterior, 1984, p. 87.

${ }^{21}$ Idem, pp. 87-88. Else Lasker-Schüler era autora do romance M alik, cujo título inspirará o nome da editora de Herzfelde; Max Reinhardt dirigia, em 1919, a Grosses Schauspiel haus; Karl Radek militava, na época, na extrema esquerda da socialdemocracia alemã.

${ }^{22}$ PISCATOR, Erwin. Op. cit., pp. 38-39.

${ }^{23}$ SCH NEEDE, U we M. Op. cit., pp. 94-96.

${ }^{24}$ DE M ICHELI, M . John Heartfield: il suo tempo, la sua attualità. In: SIEPM AN N, 
E. John H eartfield. M ilano: M azzotta, 1978, p. 9; BAITELLO, N. J. Dadá-Berlim: des/montagem. São Paulo: Annablume, 1993, pp. 57-65.

${ }^{25}$ Apud: RICH ARD, L. D'une apocalypse à I'autre: sur l'Allemagne et ses productions intellectuelles de Guillaume II aux années vingt. Paris: Union Générale d'Éditions, 1976, pp. 293-294.

${ }^{26}$ PISCATOR, E. Op. cit., p. 37.

${ }^{27}$ H AU SM AN N, R. Photomontage. Op. cit., p. 59; KRACAU ER, S. La fotografia. In: La massa come ornamento. Napoli: Prismi, 1982, p. 119.

${ }^{28}$ COSTA, H. U m olho que pensa. São Paulo: FAU -USP, 1998, v. 1, p. 52 (mimeo).

${ }^{29}$ FREU ND, G. Photographie et société. Paris: Éditions du Seuil, 1974, p. 115.

${ }^{30}$ KRACAUER, S. Op. cit., p. 123.

${ }^{31}$ KAHN, D. 0 p. cit., p. 64.

${ }^{32}$ HAUSM AN N, R. Photomontage. Op. cit., p. 61.

${ }^{33}$ Apud:TRETJAKOV, S. I montaggi di John Heartfield. In: SI EPM AN N , E. O p. cit., p. 153.

${ }^{34}$ HÖ LLERIN G, F. Photomontage. In: PHILLIPS, C. (org). Photography in the modern era: European documents and critical writings, 1913-1940. New York: The Metropolitan M useum of Art/A perture, 1989, pp. 130-131.

${ }^{35}$ TRETJAKOV, S. Op. cit., p. 154.

${ }^{36} \mathrm{KAHN}$, D. Op. cit., p. 45.

${ }^{37}$ TRETJAKOV, Sergej. Op. cit., p. 155.

${ }^{38}$ PISCATOR, E. Op. cit., pp. 51-53.

${ }^{39}$ Idem, p. 81.

${ }^{40}$ Idem, p. 84; BRECHT, B. L'essai de Piscator. In: Écrits sur le théâtre. Paris: L'Arche, 1972, v. I, pp. 133-134.

${ }^{41}$ PISCATOR, E. Op. cit., pp. 66, 68.

${ }^{42}$ TRETJAKOV, S. Op. cit., p. 152.

${ }^{43}$. CORNELSEN, E. L. O conceito de Kinostil e o princípio da montagem no romance Berlim Alexanderplatz, de Alfred Döblin. Aletria, Belo Horizonte, n. 8, p. 202-204, 2001.

${ }^{44}$ ALBERA, F. Eisenstein eo construtivismo russo: a dramaturgia da forma em "Stuttgart" (1929). São Paulo: Cosac \& Naify, 2002, p. 247.

45.WILLETT, J. Heartfield contre Hitler. Paris: Hazan, 1997, p. 29; KAH N, D. O p. cit., p. 108.

${ }^{46}$. KAH N, Douglas. Op. cit., p. 108; ALBERA, F. O p. cit., p. 241. 
${ }^{47}$ ALBERA, F. O p. cit., pp. 245, 272.

${ }^{48}$ KRACAUER, S. De Caligari a Hitler: uma história psicológica do cinema alemão. Rio de Janeiro: Jorge Zahar, 1988, pp. 212-220; KAH N, D. Op. cit., pp. 113, 116. A sociedadeUniversumfilm (UFA) surgiu em 1917 a partir da fusão de diversas companhias cinematográficas com o objetivo de fazer a propaganda da Alemanha. Tendo como meta a realização de obras de propaganda direta e de filmes dedicados à cultura ou voltados para a educação nacional, a UFA torna-se rapidamente a mais importante produtora cinematográfica do país.

${ }^{49}$ KRACAUER, S. La fotografia. Op. cit., pp. 127.

${ }^{50}$ CORNELSEN , E. L. Op. cit., pp. 199, 207-208; BENJAM IN, W. Crisi del romanzo. A proposito di Berlin Alexanderplatz di Döblin. In: Avanguardia erivoluzione: saggi sulla letteratura. Torino: Einaudi, 1979, p. 95; RICHARD, L. A República de Weimar (1919-1933). São Paulo: Companhia das Letras: Círculo do Livro, 1988, p. 258.

${ }^{51} \mathrm{KAHN}, \mathrm{D} .0$ p. cit., p. 56.

52 TRETJAKOV, S. Op. cit., p. 154.

${ }^{53}$ A mesma composição, com o título Vinte anos depois, é publicada em AIZ de 13 de setembro de 1934. Fora do campo da imagem há uma declaração extraída do periódico japonês Charbin Simbun: "M esmo às crianças de três anos, quando brincam de guerra, deve-se ensinar a manejar seriamente o fuzil e a espada einculcarIhes a sensação de que a guerra é agradável e de que se deve amar a guerra."

${ }^{54}$ HUYNH, P. Cidade-rádio, cidade-jornal. In: RICHARD, L. (Org). Berlim, 19191933: a encarnação extrema da modernidade. Rio de Janeiro: Jorge Zahar, 1993, pp. 139-142.

${ }^{55}$ KAHN , D. Op. cit., p. 65; PFÄFFLIN , F. Los fotomontajes de John H eartfield en la "Arbeiter-Illustrierte-Zeitung" (1930-1936) y en la "Volks-Illustrierte" (19361938). Una bibliografía. In: HEARTFIELD, J. Guerra en la paz: fotomontajes sobre el período 1930-1938. Barcelona: Gustavo Gili, 1976, p. 116; PATTI, G. et al. Gli strumenti e i procedimenti di Heartfield. In: SIEPM AN N, E. Op. cit., p. 24. Kahn reporta em seu livro uma informação de Karl Retzlaw: a tiragem máxima deAIZ teria sido de 280.000 exemplares.

${ }^{56}$ HÖLLERIN G, F. Op. cit., pp. 129-130.

${ }^{57}$ DURUS. Photomontage, photogram; Photomontage as a weapon in class struggle. In: PHILLIPS, C. (org). Op. cit., pp. 183-185, 206 (grifo no original).

${ }^{58}$ DU RUS. Photomontage as a weapon in class struggle. Op. cit., p. 204.

${ }^{59}$ BEN JAM I N, W. L'autore come produttore. In: Avanguardia e rivoluzione: saggi sulla letteratura. Op. cit., pp. 208-209.

${ }^{60} \mathrm{KAHN}, \mathrm{D} .0$ p. cit., p. 44. 
${ }^{61}$ POU LANTZAS, N . Fascisme et dictature. Paris: Éditions du Seuil: M aspero, 1974, pp. 100-108.

${ }^{62}$ Idem, pp. 100-108, 114-116.

${ }^{63} \mathrm{KAHN}$, D. Op. cit., pp. 82-85. Os filiados ao PSD eram, em sua maioria, empregados do setor industrial eganhavam bons salários. 0 partido tinha também adeptos nos setores têxtil, agrícola e de serviços. Cf.: POU LANTZAS, N. O p. cit, p. 207. ${ }^{64}$ KAHN , D. O p. cit., pp. 74-76; RI CH ARD, L. A República de Weimar (1919-1933). Op. cit., p. 136; POULANTZAS, N. Op. cit., p. 208.

${ }^{65}$ BAITELLO, N. Jr. O p. cit., p. 42; RICH ARD, L. A República de Weimar (19191933). O p. cit., pp. 133-135; POU LANTZAS, N. O p. cit., pp. 207-208.

${ }^{66}$ RICH ARD, L. Nazisme et littérature. Paris: M aspero, 1971, p. 144.

${ }^{67} \mathrm{O}$ paralelo entre Heartfield e Dix foi proposto em: PATTI, G. et al. Op. cit., p. 27. ${ }^{68}$ Idem, p. 26.

${ }^{69} \mathrm{~A}$ identificação de Streicher está em: HEARTFIELD, J. O p. cit., p. 55. A fotografia policial utilizada na fotomontagem está reproduzida em: SCHARF, A. Arte e fotografia. Torino: Einaudi, 1979, p. 303.

${ }^{70}$ BÜ RGER, P. Teoría de la vanguardia. Barcelona: Ediciones Península, 1987, p. 139. 0 emblema é uma figura simbólica, acompanhada, em geral, de um mote ou uma sentença.

${ }^{71}$ PISCATOR, E. Op. cit., p. 62.

${ }^{72}$ PATTI, G. et al. Op. cit., pp. 26-30.

${ }^{73}$ Idem, p. 31.

${ }^{74}$ GRAZI OLI, E. Arte e pubblicità. M ilano: Bruno Mondadori, 2001, p. 105.

${ }^{75}$ ARAGON , L. John Heartfield et la beauté révolutionnaire. In: 0 p. cit., pp. 85-88.

${ }^{76}$ LUKACS, G. Trata-se do Realismo! In: V.A. Realismo, materialismo, utopia (U ma polémica 1935-1940). Lisboa: M oraes Editores, 1978, p. 50.

${ }^{77}$ BLOCH, E. Discussing Expressionism. In:V.A. Aestheticsand politics. London/N ew York: Verso, 1990, p. 36.

${ }^{78}$ BRECHT, B. $O$ carácter popular da arte e o Realismo. In: V.A. Realismo, materialismo, utopia (Uma polémica 1935-1940). Op. cit., pp. 110-111.

${ }^{79}$ Idem, p. 113.

${ }^{80}$ WILLETT, J. O p. cit., pp. 191-192.

${ }^{81}$ As categorias fundamentais do teatro épico foram retiradas de: BENJAM IN , W. L'autore come produttore. 0 p. cit., pp. 213-214.

${ }^{82}$ ARAGON, L. John Heartfield et la beauté révolutionnaire. 0p. cit., pp. 82-83, 89. As fotomontagens a que Aragon se refere são: 0 carrasco ea justiça ( $A I Z, 30$ de no- 
vembro de 1933), relativa à presença de Goering no processo pelo incêndio do Parlamento, durante o qual declarara: "Para mim, a justiça é algo sangrento"; 0 Senhor von Papen, um ministro nada habilidoso (AIZ, 9 de agosto de 1934), que toma como mote o extravio de uma pasta de documentos relativos a Viena, para criticar a posição do governo alemão em relação ao putsch nacional-socialista de 25 de junho de 1933 e ao assassinato do chanceler Engelbert Dollfuss; 0 Reich milenário (AIZ, 20 de setembro de 1934), inspirada pelo discurso de Hitler no Congresso de Nuremberg, no qual fora anunciada a forma de vida alemã para os próximos mil anos: ausência de toda revolução. A leitura que H eartfield faz do discurso é satírica: no topo do castelo de cartas, prestes a ruir, está o magnata do aço Thyssen, que se apóia sobre Goering à esquerda. Hitler está situado ao pé do castelo, à direita, tocando tambor.

${ }^{83}$ SIEPM AN N, E. O p. cit., p. 50.

${ }^{84}$ M ARRA, C. Il contributo delle avanguardie storiche. In: ALI N OVI, F.; M ARRA, C. La fotografia: illusione o rivelazione? Bologna: II Mulino, 1981, p. 226.

${ }^{85}$ VON AM ELUN XEN , H. Dela construction de l'espace historique dans le photomontage et dans le photoreportage. In: V.A. Faceà I'histoire - 1933-1996: I'artiste moderne devant l'événement historique. Paris: Flammarion: Centre Georges Pompidou, 1996, pp. 95-96.

${ }^{86}$ TRETJAKOV, Sergej. Op. cit., p. 155.

${ }^{87}$ BEN JAM IN , W. Piccola storia della fotografia. In: L'opera d'arte nell'epoca della sua riproducibilità tecnica. Torino, Einaudi, 1974, pp. 75-76.

${ }^{88} \mathrm{ARAGON}$, L. Jonh Heartfield et la beauté révolutionnaire. 0 p. cit., p. 85.

${ }^{89}$ KRAUSS, R. Photographie et Surréalisme. In: Le photographique: pour une théorie des écarts. Paris: M acula, 1990, pp. 113-114.

Artigo recebido em 02/2003. Aprovado em 04/2003. 


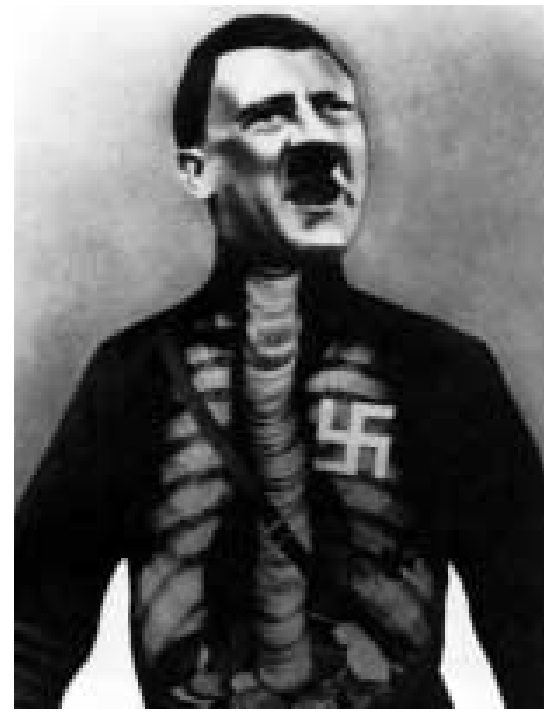

John Heartfield, 1932

Adolf, o Super-homem:

traga ouro e fala disparates

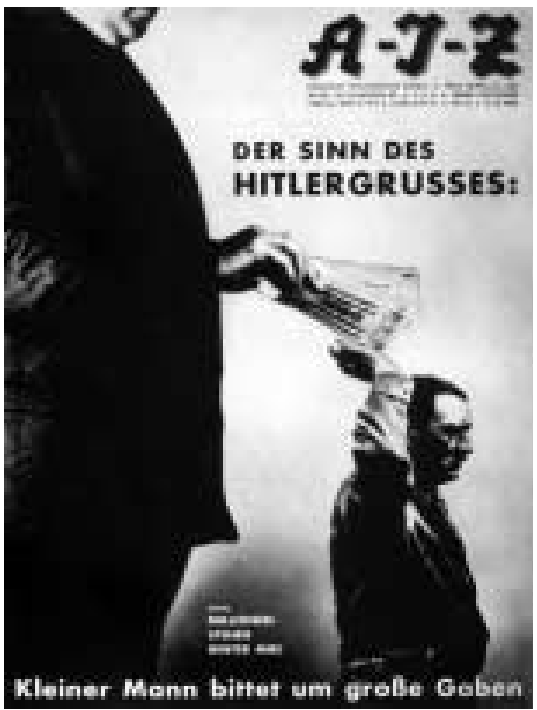

John Heartfield, 1932 O sentido da saudação hitleriana: o pequeno homem pede grandes donativos 